\title{
Optimal Monetary and Macroprudential Policies for Financial Stability in a Commodity-Exporting Economy ${ }^{1}$
}

\author{
Ivan Khotulev, Bank of Russia \\ khotulevim@cbr.ru
Konstantin Styrin, Bank of Russia
styrinka@cbr.ru

We develop a model of analysing the optimal combination of macroprudential and monetary policies in a small open commodityexporting economy. Unlike a closed economy, where monetary and macroprudential policies tend to be substitutes, in a small open economy the optimal policy mix depends on the specifics of shocks and economic structure. Monetary and macroprudential policies tend to complement each other when the degree of pass-through of credit spreads into marginal costs and prices are sufficiently high, or when a credit boom is caused by a commodity boom, a fraction of consumers lacks access to financial markets, and the government follows a fiscal policy rule. The two policies are substitutes when the complementarity between domestic and imported production inputs is sufficiently high.

Keywords: monetary policy, macroprudential policy, financial stability, commodity exporter, small open economy

JEL Codes: E52, E58, G01, G28
Citation: Khotulev, I. and Styrin, K. (2020). Optimal Monetary and Macroprudential Policies for Financial Stability in a Commodity-Exporting Economy. Russian Journal of Money and Finance, 79(2), pp. 3-42.

doi: $10.31477 /$ rjmf.202002.03

\section{Introduction}

The question of how a benevolent policymaker should respond to businesscycle fluctuations is one of the most fundamental in macroeconomics. This paper studies macroeconomic stabilisation policies in a small open economy,

\footnotetext{
1 The authors are grateful to Zuzana Fungáčová, Iikka Korhonen, Yulin Liu, Alexander Morozov, Sergei Seleznev, Andrey Sinyakov, Laura Solanko, Yulia Ushakova, Ksenia Yudaeva, participants of the XIX and XX April International Academic Conferences at the Higher School of Economics in Moscow, seminar participants at the Bank of Russia and the Bank of Finland Institute for Economies in Transition (BOFIT), and three anonymous referees for their comments and suggestions. Part of this research was undertaken when Ivan Khotulev was a visiting researcher at BOFIT in Helsinki. BOFIT's hospitality is gratefully acknowledged. Any remaining errors are the authors' responsibility.
} 
such as Russia, where commodities, such as oil, metals, or wheat, compose a significant part of exports. World prices of primary commodities are determined in international markets. Therefore, commodity export prices are perceived as exogenous by a small open commodity-exporting economy. Furthermore, world prices are difficult to predict. A rise in exogenous world commodity export prices can suppress a country's risk premium and lead to a credit boom, as documented in Shousha (2016). Empirical evidence in Gourinchas and Obstfeld (2012) and Schularick and Taylor (2012) suggests that credit booms are good predictors of financial crises. Nevertheless, private agents in a commodity-exporting economy may be myopic and assign a zero probability to a systemic financial crisis in the aftermath of a credit boom. A benevolent policymaker, however, may be more foresighted and correctly estimate the probability of a crisis. This paper studies possible reactions of monetary and macroprudential policies in response to a temporary commodity export price shock that, by igniting a credit boom, can lead to a systemic crisis. We also take for granted that a commodity-exporting economy has an established fiscal policy rule, which is common practice among commodity exporters.

To model an oil-exporting economy, we use a simple three-period New Keynesian general equilibrium model of a small open economy based on Lorenzoni (2014). In the first period, the economy rests in its initial steady state. A representative private agent maximises a utility function that depends on private consumption and labour. Production of domestic differentiated nontradable consumption goods requires private agent's labour and an imported homogeneous intermediate input. For simplicity, oil-export revenue is given as an exogenous flow of income expressed in foreign currency that requires no labour input. The small open economy trades with the rest of the world in a risk-free one-period discount bond denominated in foreign currency. Fiscal authorities are also endowed with non-zero international bond holdings, i.e. a 'sovereign wealth fund.' There is no uncertainty in the steady state.

In the second period, the economy is hit by an unanticipated shock. We consider two sources of shocks: an exogenous world oil price shock and a credit growth shock. The first disturbance is a shock in oil-export revenue that is modelled as a one-time change in the exogenous flow of income denominated in foreign currency. This change is unexpected both for private agents and for policy authorities. We assume that a fraction of domestic differentiated goods producers cannot change their optimal prices. Price stickiness is required for modelling the effects of monetary policy, which is given as a short-term (one-period) interest rate set by monetary authorities. Fiscal policy authorities conduct their policy according to an established rule by taxing private agents' oil income. To model nontrivial effects of fiscal policy, two types of consumers are introduced. A fraction of consumers are Ricardian with access to financial markets. Others are non-Ricardian: they can neither borrow nor save, and act as 'hand-to-mouth' workers. 
Aside from monetary and fiscal policies, the third instrument is macroprudential policy. To explain nontrivial effects of macroprudential policy, we introduce a credit spread, as in Cúrdia and Woodford (2016), on the aggregate demand side (Euler's equation) and on the aggregate supply side (the New Keynesian Phillips curve). To simplify analysis, the whole credit block is modelled outside of the general equilibrium model in an ad hoc fashion. The credit spread is not microfounded but is rather calibrated based on empirical evidence, as in Ajello et al. (2019) or Aikman et al. (2018). The spread is assumed to be a function of a parameter that characterises the stance of macroprudential policy. The parameter is labelled the Countercyclical Capital Buffer (CCyB) for concreteness. One important empirical regularity of commodity-exporting economies is a positive correlation between commodity export prices and domestic credit growth. Therefore, 'credit' growth in the credit block of the model is an empirically estimated function of a short-term interest rate, credit spread, and oil-export revenue.

The second type of shocks that we consider in addition to oil-export revenue is a shock to credit growth, which is a disturbance term in the credit growth equation. Furthermore, credit growth and bank capital affect the probability of a 'financial crisis' in the third period. A 'crisis' in the model is a persistent exogenous fall in labour productivity and/or an exogenous fall in oil-export revenue. In this way, the credit block, which is left outside of general equilibrium, is still connected to the main part of the general equilibrium model. As already mentioned, an important assumption we make is that private agents are myopic: they always assign zero probability to a crisis in the third period. On the contrary, policy authorities correctly anticipate the possibility of a crisis. Policy authorities conduct macroprudential policy by setting the $\mathrm{C} C \mathrm{BB}$ parameter, which influences contemporaneous credit growth and thus affects the likelihood of a crisis.

In the third period, all prices become flexible, financial frictions evaporate, and the economy reaches a new steady state, either with a crisis or without it. The model is calibrated and solved by log-linearising equilibrium conditions in the neighbourhood of the initial first period steady state. In the study, we find combinations of the policy rate and the $\mathrm{CCyB}$ parameter in response to a shock in the second period that minimise the loss function of the policymaker under alternative fiscal policy scenarios. The policy loss function depends on the variance of output and inflation, with a special weight on crisis prevention, as in Aikman et al. (2018).

Challenges in modelling macroprudential policy are well known. There is no canonical framework yet, i.e. a micro-founded DSGE model that would feature financial crises as endogenous events. The early generation of models such as Gerali et al. (2010) and Angelini et al. (2014) treat financial intermediation as a safe activity of channelling funds from savers to borrowers with no risks of bank runs and/ or insolvency involved. As a consequence, bankruptcies of individual institutions 
or systemic crises are missing from those models. Cúrdia and Woodford (2016) develop a version of the New Keynesian model with heterogeneous consumers, some of them being more patient than others. The intermediation of savings from the patient to the impatient requires some physical cost. Furthermore, a fraction of loans known in advance gets sour. Banks do not fail in this model since they make up for the anticipated loan losses by the credit spread, the difference between the interest rate on loans and deposits. Woodford (2012) employs a version of this model to analyse the role of monetary policy in achieving financial stability. The credit spread is set to take on two values, low in normal times and high in crisis times. The probability of a crisis depends on the credit growth that does not appear explicitly in the two-equation New Keynesian model for a closed economy, but is rather postulated to depend positively on the level of economic activity. A high realisation of the credit spread is a metaphor for disrupted financial intermediation during a financial crisis. Gertler and Kiyotaki (2015) develop a dynamic general equilibrium model where bank runs occur with a (postulated) probability that depends on the state of the economy and the capital ratio of banks.

In this paper we take a minimalist approach developed by Ajello et al. (2019) and Aikman et al. (2018). Ajello et al. (2019) construct a two-period closed economy New Keynesian model in which the economy can experience a crisis in the second period depending on credit conditions in the first. The model consists of an IS (Euler) equation and a New Keynesian Phillips curve. There are two possible states on date 2: normal or crisis. The probability of a crisis is a logistic function of lending growth, which, in turn, depends on the interest rate, output gap, and inflation. Lending growth and the probability of a crisis are modelled outside of general equilibrium as empirically estimated functions. Schularick and Taylor (2012) and Gourinchas and Obstfeld (2012) show empirically that, retrospectively, credit growth is a good predictor of financial crises. The policy maker chooses the interest rate policy by optimising a loss function that depends on output gap and inflation. The authors find that the optimal response of the short-term interest rate to credit conditions is very small. They also consider policy under parameter uncertainty. Bayesian and robust policy makers will respond more aggressively when the probability and severity of a crisis are uncertain.

Unlike Ajello et al. (2019), who only consider short-term interest rate policy, Aikman et al. (2018) study the interaction between monetary and macroprudential policies. They also construct a two-period closed economy New Keynesian model consisting of an IS (Euler) equation, a New Keynesian Phillips curve, a lending growth equation, and a probability of a crisis equation. Their loss function includes a special weight on crisis prevention. Macroprudential policy is modelled as a CCyB - a variable that affects a credit spread. The spread, in turn, affects credit growth. The authors show that using the CCyB improves outcomes compared to using the short-term interest rate alone, with the two instruments typically being substitutes. 
Our paper is motivated by empirical evidence on the link between commodity and financial cycles. Shousha (2016) estimates a panel VAR and an open-economy multi-sector DSGE model with financial frictions on a number of emerging and advanced commodity exporters. Commodity price shocks turn out to be an important source of business cycle fluctuations in commodity-exporting countries, especially in emerging markets. The structural model also allows the author to conduct counterfactual exercises. He finds that the main sources accounting for heterogeneous responses of emerging and advanced economies to commodity price shocks are the different responses of country interest rates and the variations in firms' working capital constraints. In our paper, we use the empirical result that a surge in commodity prices suppresses the risk premium on the debt of commodity exporters and attracts capital inflows to those countries. We use it to motivate our model in which a commodity boom gives rise to a credit boom that potentially leads to a financial crisis. For further empirical evidence, see, for example, Drechsel and Tenreyro (2018).

This paper continues the tradition of studying optimal stabilisation policies in commodity-exporting economies. However, existing studies typically consider either one or two policies among possible combinations of fiscal, monetary, and macroprudential policies. Medina and Soto (2016) build a DSGE model describing the business cycle in Chile, a major copper exporter, and use it to simulate the effects of various fiscal rules. Snudden (2016) uses an extension of the International Monetary Fund's Global Integrated Monetary and Fiscal Model (GIMF) to study a combination of fiscal rules with fixed exchange rates or inflation targeting in oilexporting countries. Agénor (2016) studies how fiscal policy should respond to commodity price shocks, accounting not only for macroeconomic stability but also for spending on public infrastructure. Van der Ploeg (2019) shows how a typical recipe of managing natural resource windfalls based on public and private consumption smoothing should be modified to account for capital scarcity and the need to invest in the domestic economy; he also studies the combination of fiscal rules with nominal exchange rate pegs or a Taylor rule of monetary policy.

Among papers that mostly stress monetary policy, Catão and Chang (2013) compare targeting monetary policy rules and Ramsey allocations under perfect risk sharing and financial autarky for a small open economy that exports commodities and experiences realistic random fluctuations in world prices. Bergholt (2014) stresses the importance of non-oil firms, some of which are linked to the oil sector via supply chains, in comparing welfare implications of alternative policy rules. Ferrero and Seneca (2019) stress the trade-off between lowering the policy rate in order to close a negative output gap following a drop in oil prices for an oil exporter, on one hand, and raising the rate in order to fight inflationary pressures caused by an exchange rate depreciation. Hamann et al. (2016) estimate a model for Colombia and stress the same trade-off, however, they also model the oil sector as an optimal extraction problem and show that macroeconomic effects depend on the degree of 
persistence of oil-price shocks. Drygalla (2017) estimates a model for Russia and compares welfare implications of oil-price and other shocks under an inflationtargeting regime adopted by the Bank of Russia since 2014 with alternative regimes, such as targeting the nominal exchange rate. Charnavoki (2019) studies welfare terms-of-trade costs of alternative regimes, including nominal peg, core consumer inflation targeting, and non-commodity domestic inflation targeting, under complete international asset markets vs. financial autarky and under producer vs. local currency pricing for tradable goods.

Several recent papers stress financial stability and macroprudential policy in small open economies and emerging markets. González et al. (2015) estimate a DSGE model for Colombia and stress the reallocation of credit to the nontradable sector during commodity booms and to the tradable during busts; they simulate the effects of short-term interest rates, FX intervention, and financial regulation (macroprudential policy) on the credit cycle. Lozej et al. (2018) construct a DSGE model of a small open economy in a monetary union in order to study the performance of various $\mathrm{CCyB}$ rules and find that a rule targeting housing prices improves welfare compared to the rule based on the credit gap. Menna and Tobal (2018) extend the closed economy New Keynesian model with a credit block similar to Cúrdia and Woodford (2016) to an open economy setting in order to study the applicability of the 'lean against the wind' policy - a policy of raising the interest rate to curb the buildup of systemic risk - in emerging market economies (EMEs); they find that a strong dependence of domestic financial conditions on capital flows reduces the effectiveness of monetary policy.

Among papers that stress mostly empirics, Drechsel and Tenreyro (2018) construct a small open economy DSGE model for a net commodity exporter; their model is able to account for most of the stylised facts of emerging markets business cycles including a large contribution of commodity prices to the volatility of output, consumption, and investment growth. Fernández et al. (2018) use principal component analysis to identify a common factor that drives commodity prices as well as business cycle macro variables of commodity exporting emerging market economies; they construct a DSGE model in which commodity prices and risk premia faced by commodity exporters in world capital markets move in opposite directions. Recent work by Schmitt-Grohé and Uribe (2018) has questioned the common wisdom that commodity term of trade shocks explain a sizable portion of macroeconomic volatility in EMEs by estimating an annual structural VAR and finding that terms of trade shocks explain on average only $10 \%$ of aggregate volatility. In response, Ben Zeev et al. (2017) identify news-augmented commodity terms of trade shocks and find that they explain about half of output fluctuations in EMEs. Finally, Bejarano et al. (2016) build a model in which agents are uncertain about the persistence parameters of the commodity price swings and have to learn true persistence through Bayesian learning; the model is able to reproduce the boom-bust cycle in foreign borrowing typical in commodity-exporting economies. 
This paper studies the optimal design of macroeconomic policies for a small open commodity-exporting economy. It addresses the following questions. What is the optimal mix of monetary and macroprudential policies for a small open commodity-exporting economy taking fiscal policy as given? How does the optimal response depend on the source of disturbance that hits the economy? Our work builds on two recent papers, Ajello et al. (2019) and Aikman et al. (2018), which apply a canonical two-equation New Keynesian model augmented with financial frictions to the analysis of financial stability. We extend the framework developed in those papers to the case of a small open commodity-exporting economy.

The contribution of this paper relative to previous studies is a simultaneous modelling of monetary and macroprudential policies in a small open economy in response to two types of shocks taking a fiscal policy rule for granted. The first type of shocks is a shock to the credit growth ('credit boom') independent of an oil-price shock. The second is an oil-price shock that also triggers a credit boom. Our results show that whether monetary and macroprudential policies are complements or substitutes depends on the nature of the shock and on particularities of the economic structure. This finding contrasts with the closed economy case studied in Aikman et al. (2018) where the two policies tend to be substitutes, i.e. macroprudential tightening should be accompanied by monetary easing in a closed economy.

We find that whether monetary and macroprudential policies are substitutes or complements depends on a few key parameters. The two policies complement each other when the degree of pass-through of credit spreads into marginal costs and prices is sufficiently high. This is opposite to the closed economy case, where monetary and macroprudential policies are always substitutes, i.e. a tighter stance of one policy requires a looser stance of the other. If credit growth is induced by a commodity boom, and some workers are hand-to-mouth with no access to financial markets, then monetary policy tends to be complementary to macroprudential policy. Monetary policy takes on an additional task of correcting intertemporal resource allocation distorted by sticky prices that is only imperfectly fixed by the structural balance fiscal rule. Finally, a higher degree of complementarity between domestic and imported production inputs makes macroprudential and monetary policies substitutes.

The rest of the paper is organised as follows. Section 2 describes the model; Section 3 reports and discusses our findings; Section 4 concludes. Appendix contains a complete list of equations of the log-linearised model of Section 2.

\section{Model}

We consider a small open, effectively three-period economy similar to Lorenzoni (2014). The economy exports a commodity that will be referred to as oil. The oil export revenue is modelled as an exogenous flow of income denominated 
in the foreign currency, dollars. The time horizon is infinite. Initially, on date 0 , the economy rests in a deterministic steady state with flexible prices and no financial frictions. There is no uncertainty except for one of the two unanticipated shocks (ex ante zero-probability shocks, a.k.a. 'MIT shocks') on date 1 and another shock (with positive probability) on date 2 . We consider two different shocks that might hit the economy on date 1 . Both shocks are correctly perceived as transitory by private agents and by the government. The first one is an unanticipated shock to the commodity export revenue. The second disturbance is a shock to the growth of credit in the economy. On date 1 , the economy features nominal price rigidity and financial frictions in the form of credit spreads. On date 2 , the economy finds itself in a new deterministic steady state and remains in this state forever. The state is either normal or crisis, with lower level of output. Starting from date 2, there are no shocks; nominal prices are fully flexible; financial frictions evaporate. Following Ajello et al. (2019) and Aikman et al. (2018), we postulate that the probability of a crisis on date 2 positively depends on the credit growth on date 1 . Motivated by the empirical evidence reported in Shousha (2016) or Drechsel and Tenreyro (2018), we also allow the credit growth on date 1 to be positively associated with the oil revenue shock on date 1. Similarly to Ajello et al. (2019) and Aikman et al. (2018), we assume that private agents mistakenly assign zero probability to the crisis state on date 2. In the normal state on date 2 , the economy produces the potential level of output. In the crisis state, the output drops below its potential level and remains there forever. This modelling shortcut is meant to capture the idea that output is depressed due to disrupted financial intermediation. The post-crisis permanent drop in output should be understood in present value terms. The present value of the permanent cut in potential output in the crisis state is equal to the present value of actual output loss due to a recession triggered by the financial crisis.

In the remaining sections, we build our theoretical framework in two steps. We consider a small open economy version of Ajello et al. (2019) and Aikman et al. (2018) models. To develop some intuition, we first consider a special case of the small open economy model with exogenously imposed financial frictions but without a fiscal sector. Then we add a fiscal policy to the model assuming that the government (i) receives a constant share of export revenue in taxes; (ii) has access to international capital markets where it can save or borrow; and (iii) follows a fiscal rule by spending an equivalent of its 'permanent income' in the textbook theory of consumption, i.e. what Medina and Soto (2016) label as running a structural balance fiscal rule. Although government consumption does not directly affect the well-being of households in the model, the rationale for the fiscal rule is the presence of the so-called 'hand-to-mouth' or non-Ricardian workers who do not have access to either internal or external financial markets. For each type of date 1 disturbance, we find optimal monetary and macroprudential policy responses and compare them with a similarly parameterised closed economy. 


\subsection{Small open economy with the representative household and without a fiscal sector}

Time is discrete. The representative household is endowed with an exogenous flow of the internationally traded good $X$, which we label 'export revenue' or 'oil revenue.' Changes in oil-export revenues are modeled as variations in $X_{t}$. Along with trade in goods, there is trade in the riskless international bond denominated in dollars between the small open economy and the rest of the world. Whereas oil revenue is exogenous, differentiated varieties of the domestic non-traded good are produced by a unit mass of monopolistically competitive firms using the imported intermediate good and the household's labour as inputs according to the CobbDouglas production function:

$$
Y_{t}(j)=N_{t}(j)^{\alpha} M_{t}(j)^{1-\alpha}, \quad 0<\alpha<1,
$$

where $Y_{t}(j)$ is the amount of a differentiated variety of the final good produced by firm $j$, and $N_{t}(j)$ and $M_{t}(j)$ are, respectively, the amount of labour and the amount of the traded intermediate input (i.e. materials) involved in the production of $Y_{t}(j)$. Different varieties of the final good are subsequently repacked into a homogeneous final composite good by perfectly competitive retailers according to the constant elasticity of substitution (CES) technology:

$$
Y_{t}=\left(\int_{0}^{1} Y_{t}(j)^{\frac{\theta-1}{\theta}} d j\right)^{\frac{\theta}{\theta-1}}, \quad \theta>1,
$$

where $Y_{t}$ is the quantity of the final composite good produced from differentiated varieties $Y_{t}(j)$. The zero profit condition for retailers requires the relationship between the price of the final composite good and prices of its differentiated components to be

$$
P_{t}=\left(\int_{0}^{1} P_{t}(j)^{1-\theta} d j\right)^{\frac{1}{1-\theta}},
$$

where $P_{t}(j)$ is the price of differentiated variety $j$.

A representative household's preferences are given by:

$$
\sum_{t=0}^{\infty} \beta^{t} \mathbb{E}_{t}^{p s}\left(\frac{C_{t}^{1-\sigma}}{1-\sigma}-\psi \frac{N_{t}^{1+\phi}}{1+\phi}\right),
$$

where $C_{t}$ is the consumption of the final composite good, and $N_{t}$ is hours worked.

Representative household's one-period budget constraint is

$$
\varepsilon_{t} M_{t}+\varepsilon_{t} \beta B_{t}+P_{t} C_{t}=\varepsilon_{t} X_{t}+\varepsilon_{t} B_{t-1}+W_{t} N_{t}+D_{t}
$$

where $\varepsilon_{t}$ is the nominal exchange rate, $W_{t}$ is nominal wage, $D_{t}$ is nominal profits of monopolistically competitive firms plus intermediate import costs, $B_{t}$ is the 
amount of the international one-period discount bond held at the end of date $t$ maturing on date $t+1, \beta$ is its exogenous market price, which coincides with the subjective time discount factor of households, and $M_{t}$ is the total amount of imported intermediate input, defined as

$$
M_{t}=\int_{0}^{1} M_{t}(j) d j .
$$

Given that the final composite good is not traded internationally and must be, therefore, entirely consumed domestically, i.e.

$$
C_{t}=Y_{t}
$$

representative household's one-period budget constraint yields the standard balance of payments relationship:

$$
M_{t}+\beta B_{t}=X_{t}+B_{t-1}
$$

The balance of payments relationship acknowledges that total income is split into wages and profits of monopolistic competitors:

$$
P_{t} Y_{t}=W_{t} N_{t}+D_{t}
$$

Optimality conditions are as follows. The Euler equation, which characterises the optimal choice of the intertemporal consumption profile, is:

$$
C_{t}^{-\sigma}=\beta\left(1+i_{t}\right) \mathbb{E}_{t}^{p s}\left[C_{t+1}^{-\sigma} \frac{P_{t}}{P_{t+1}}\right]
$$

The superscript $p s$ on the conditional expectation operator indicates that expectations of the private sector may deviate from fully rational. The specific assumption is that private agents have rational expectations in all periods except for $t=1$. In period $t=1$, however, they assign a zero probability to the occurrence of a financial crisis on date $t=2$ :

$$
\begin{gathered}
\mathbb{E}_{t}^{p s} \equiv \mathbb{E}_{t}, t \leq 0, t \geq 2, \\
\mathbb{E}_{1}^{p s}\left[Y_{2}\right]>\mathbb{E}_{1}\left[Y_{2}\right] .
\end{gathered}
$$

The uncovered interest parity, which, in this context, is equivalent to the noarbitrage condition for foreign and domestic bonds, is:

$$
1+i_{t}=\left(1+i^{*}\right) \frac{\mathbb{E}_{t}^{p s} \varepsilon_{t+1}}{\varepsilon_{t}}
$$


The labour supply relationship, which characterises optimal intratemporal choice between consumption and leisure, takes the form:

$$
\frac{W_{t}}{P_{t}} C_{t}^{-\sigma}=\psi N_{t}^{\phi} \text {. }
$$

Note that equations (9) and (10) involve the conditional expectation operator with superscript $p s$ indicating that expectations of the private sector may deviate from fully rational. This is due to our assumption that all date 1 shocks are unanticipated and have zero probability ('MIT shocks') and that, beyond date 1, no other shocks are rationally anticipated by private agents.

In what follows, we analyse the following generic scenario. Until date 1 the economy rests in a deterministic steady state with no shocks anticipated, no financial frictions and fully flexible nominal prices. On date 1, one or two disturbances exogenous credit growth shock and/or oil revenue shock - materialise. On date 1, goods prices are subject to nominal rigidity, and financial frictions take the form of credit spreads. Starting from date 2, prices become fully flexible again, and financial frictions are gone. The economy, however, finds itself either in the normal state or in the crisis state with output below the potential. In the case of a closed economy, this structure reduces to a familiar two-equation New Keynesian model employed in Ajello et al. (2019) and Aikman et al. (2018).

Sticky prices on date 1 are modelled in a simple way. Only a fraction $1-\xi$, $0<\xi<1$, of differentiated goods producers get the opportunity to reset their prices whereas the rest keep their prices unchanged from the previous period, date 0 .

Financial frictions on date 1 are introduced in an ad hoc manner, similarly to Ajello et al. (2019) and Aikman et al. (2018). We model financial frictions by plugging a credit spread in the date 1 Euler equation and the date 1 price setting equation for reoptimising producers. Cúrdia and Woodford (2016) derive microfounded Euler and Phillips curve equations featuring a credit spread for a closed economy. These authors depart from the assumption of a representative household and instead allow the time preference parameter $\beta$ to vary across two groups of households, making one of them relatively patient and, hence, willing to save in equilibrium, and the other relatively impatient, and, hence, willing to borrow. The type of each household is subject to occasional random switches. In our study, we take their findings for granted and embed credit spreads manually into the Euler and the price-setting equations that are derived within the standard New Keynesian representative household framework. In that respect, we apply the approach of Ajello et al. (2019) and Aikman et al. (2018) to the case of a small open economy.

We now describe the date 1 shock. At $t=0$, the economy is in a steady state with no shocks being anticipated. At $t=1$, a positive oil price shock (or, alternatively, credit growth shock), which is modeled as an exogenous increase in $X_{1}$ (respectively, in the growth of credit $L_{1}$; see below). Both private agents and the government correctly anticipate that oil export revenues will return to the 
same steady state value after one period: $X_{2}=X_{0}$. There is no fiscal policy in this simplified version of the model.

We now describe the monetary and the macroprudential policy responses. Since prices are sticky at $t=1$ and only a fraction $1-\xi$ of producers can adjust their prices, price stickiness justifies monetary policy intervention. The rationale for macroprudential policy arises due to the fact that private agents underestimate the probability of a financial crisis and the resulting drop in output on date 2 . Macroprudential policy affects credit spread $s_{1}$, which is added to the Euler equation and the price setting equation by hand, similarly to Ajello et al. (2019) and Aikman et al. (2018), with reference to Cúrdia and Woodford (2016). The date 1 Euler equation becomes:

$$
C_{1}^{-\sigma}=\beta\left(1+i_{1}\right)\left(1+s_{1}\right) \mathbb{E}_{1}^{p s}\left[C_{2}^{-\sigma} \frac{P_{1}}{P_{2}}\right],
$$

where $i_{1}$ is date 1 monetary policy rate. Again, the superscript $p s$ on the conditional expectation operator indicates that expectations of the private sector on date 1 are not fully rational. The spread is determined by the $\mathrm{CCyB}$ parameter $k_{1}$ as:

$$
S_{1}=\psi_{k} k_{1} .
$$

The profit-maximising price of firms that get the opportunity to reset their price on date 1 is:

$$
P_{1}^{\text {flex }}=\frac{\theta}{\theta-1}\left(\frac{W_{1}}{\alpha}\right)^{\alpha}\left(\frac{\mathcal{E}_{1}}{1-\alpha}\right)^{1-\alpha}\left(1+s_{1}\right)^{\eta},
$$

where the parameter $\eta>0$ characterises the degree of pass-through of credit spreads into marginal costs and goods prices.

The general price level on date 1 is determined as

$$
P_{1}=\left((1-\xi)\left(P_{1}^{\text {flex }}\right)^{1-\theta}+\xi\left(P_{1}^{f i x}\right)^{1-\theta}\right)^{\frac{1}{1-\theta}},
$$

where $P_{1}^{f i x}=P_{0}$ is the price of firms that do not reset their price on date 1 .

The probability of a financial crisis on date 2 known to policymakers but unknown to households is:

$$
\gamma_{1}=\frac{\exp \left(h_{0}+h_{L} L_{1}+h_{k} k_{1}\right)}{1+\exp \left(h_{0}+h_{L} L_{1}+h_{k} k_{1}\right)}, \quad h_{L}>0, h_{k}<0,
$$

where $L_{1}$ is credit growth that does not appear in the general equilibrium core of the model. This relationship is postulated based on empirical evidence (Ajello et al., 2019; Aikman et al., 2018).

Credit growth on date 1 is:

$$
\begin{aligned}
& L_{1}=\phi_{0}+\phi_{i} i_{1}+\phi_{s} s_{1}+\phi_{X} \hat{X}_{1}+\xi_{1}^{L}, \\
& \qquad \phi_{0}>0, \phi_{i}<0, \phi_{s}<0, \phi_{X}>0,
\end{aligned}
$$


where $\xi_{1}^{L}$ is exogenous credit growth shock unrelated to the oil revenue shock $\hat{X}_{1} \equiv\left(X_{1}-X_{0}\right) / X_{0}$. Similarly to the probability of a crisis (12), the relationship (13) is also obtained empirically and made an ad hoc ingredient of the model (Ajello et al., 2019; Aikman et al., 2018). Macroprudential policy involves a tradeoff since a higher spread lowers the probability of a crisis at the expense of depressed economic activity.

The policy objective is a welfare loss function inspired by Aikman et al (2018):

$$
\begin{aligned}
W L_{1} & =\frac{1}{2}\left(\pi_{1}^{2}+\lambda\left(\hat{Y}_{1}-\hat{Y}_{1}^{f l e x}\right)^{2}\right) \\
& +\frac{1}{2} \beta \lambda\left((1+\varsigma) \gamma_{1}\left(\hat{Y}_{2}^{c}-\hat{Y}_{2}^{f l e x}\right)^{2}+\left(1-\gamma_{1}\right)\left(\hat{Y}_{2}^{n c}-\hat{Y}_{2}^{f l e x}\right)^{2}\right) .
\end{aligned}
$$

Here, $\hat{Y}_{t}^{\text {flex }}, t=1,2$, is the 'natural' level of output (in log-deviations from date $Y_{0}$ ) that would prevail if all prices were flexible and no crisis occurred on date $2 ; \hat{Y}_{2}^{c}$ and $\hat{Y}_{2}^{n c}$ are the crisis and no crisis levels of output (in log-deviations from $Y_{0}$ ), respectively, with $\hat{Y}_{2}^{c}=(1-\delta) \hat{Y}_{2}^{n c}$, where $0<\delta<1$ is a fraction of output lost due to financial crisis; $\pi_{1}$ is inflation; $\gamma_{1}$ is the probability of a crisis; $\lambda$ is the relative weight on output stabilisation in the policymaker preferences; $\zeta$ is a special weight on crisis prevention.

It is worth mentioning that perhaps a more appropriate specification of the welfare loss function would involve $\beta /(1-\beta)$ rather than $\beta$ in the third and fourth terms on the right-hand side, given that our model features an infinite horizon. We have made this choice deliberately to make our results for a small open economy comparable with those of Aikman et al (2018) for a closed economy. Qualitatively, our main results survive once we move to the alternative specification.

\subsection{Small open economy with Ricardian and non-Ricardian households and a fiscal rule}

We now describe the full version of our small open economy model that features a fiscal rule. There are now two types of households in the economy, Ricardian and non-Ricardian. Ricardian households have access to the international and domestic financial markets. The only asset that is traded on the international financial market is a riskless one-period discount bond denominated in the foreign currency. The domestic financial market is assumed frictionless in all periods except date $t=1$. Similarly to the simplified model of the previous subsection, the financial friction takes the form of a credit spread in the Euler equation of Ricardian households and in the marginal costs of firms. Non-Ricardian households cannot borrow or save and act essentially as hand-to-mouth workers. The non-Ricardian households are introduced into the model in order to give some power to the fiscal policy since otherwise the Ricardian equivalence would hold (Medina and Soto, 2016).

Literally speaking, the international financial market is modelled as frictionless on all dates, allowing borrowing or saving at an exogenously given rate $i^{*} \equiv 1 / \beta-1$. 
Implicitly, though, it is assumed (although not formally modelled) that there is a financial sector in the small open economy. Only financial intermediaries can access the international capital market, borrow at the risk-free rate, accept deposits from domestic savers, and extend loans to domestic borrowers. Specifically, what we have in mind is an open-economy version of the Cúrdia and Woodford (2016) closedeconomy model with two types of agents and access to the domestic financial market intermediated by competitive banks. In that model, due to the existence of a credit spread caused by the cost of intermediation and anticipated loan losses, the marginal utility of consumption of patient (depositors) and impatient (borrowers) households is not equalised in equilibrium. As shown in Cúrdia and Woodford (2016), the difference in marginal utility of consumption between the two types of agents creates a wedge in the aggregate Euler equation, which is related to the credit spread. Of course, a bank that borrows from abroad to lend domestically is subject to exchange rate risk. We assume that banks' potential losses due to a depreciation of the domestic currency are covered by lump-sum transfers from households. Similarly, all profits caused by an appreciation of the domestic currency are distributed as lump-sum dividends. Menna and Tobal (2018) introduce a financial intermediation sector into a small-open economy model in a similar way. Unlike us, however, they allow domestic savers to purchase foreign bonds directly. In our model, all financial transactions, both intra-border and cross-border, are intermediated by banks.

Preferences are assumed the same as in the simplified model of the previous subsection:

$$
\sum_{t=0}^{\infty} \beta^{t} \mathbb{E}_{t}^{p s}\left(\frac{\left(C_{t}^{i}\right)^{1-\sigma}}{1-\sigma}-\psi \frac{\left(N_{t}^{i}\right)^{1+\phi}}{1+\phi}\right)
$$

where $i \in\{R, N R\}$ is a type of a household, and $R$ and $N R$ stand for Ricardian and non-Ricardian, respectively. The fraction of households that are non-Ricardian is assumed to be $v \in(0,1)$.

Non-Ricardian, or hand-to-mouth, households maximise their utility subject to a one-period budget constraint in equation (15):

$$
C_{t}^{N R}=w_{t} N_{t}^{N R}+(1-\tau) e_{t} X_{t}
$$

where $C_{t}^{N R}$ and $N_{t}^{N R}$ are their consumption and hours worked, respectively, $w_{t}=W_{t} / P_{t}$ is the real wage, and $e_{t}=\varepsilon_{t} / P_{t}$ is the real exchange rate. In addition to the labor income, they receive a fraction $(1-\tau) \in(0,1)$ of the oil revenue. By assumption, they do not have access to the financial markets and consume all their current income in every period.

The one-period budget constraint of the Ricardian households, their fraction being $(1-v) \in(0,1)$, is

$$
e_{t} M_{t}+e_{t} \beta B_{t}+C_{t}^{R}=e_{t} X_{t}+e_{t} B_{t-1}+w_{t} N_{t}^{R}+d_{t}
$$


where $C_{t}^{R}$ and $N_{t}^{R}$ are their consumption and hours worked, respectively, $d_{t}=D_{t} / P_{t}$ is the real profits of monopolistically competitive firms plus intermediate import costs, $B_{t}$ is the amount of the international one-period discount bond held at the end of date $t$ maturing on date $t+1$, and $\beta$ is its exogenous market price, which coincides with the subjective time discount factor of households, and $M_{t}$ is the aggregate amount of imported materials.

Households' optimisation subject to their respective budget constraints leads to equations (16) and (17) that characterise labour supply decisions by non-Ricardian and Ricardian households, respectively:

$$
\begin{gathered}
w_{t}\left(C_{t}^{N R}\right)^{-\sigma}=\psi\left(N_{t}^{N R}\right)^{\phi}, \\
w_{t}\left(C_{t}^{R}\right)^{-\sigma}=\psi\left(N_{t}^{R}\right)^{\phi} .
\end{gathered}
$$

Whereas non-Ricardian households consume their income period-by-period, optimisation by Ricardian households leads to Euler equations (18) and (19) associated with investments in home and foreign bonds, where $i_{t}$ and $i^{*}$ are home and foreign interest rates, $\pi_{t}$ is the rate of inflation, and $s_{t}$ is the credit spread:

$$
\begin{gathered}
\left(C_{t}^{R}\right)^{-\sigma}=\beta\left(1+i_{t}\right)\left(1+s_{t}\right) \mathbb{E}_{t}^{p s}\left[\frac{\left(C_{t+1}^{R}\right)^{-\sigma}}{1+\pi_{t+1}}\right], \\
\left(C_{t}^{R}\right)^{-\sigma}=\beta\left(1+i^{*}\right)\left(1+s_{t}\right) \mathbb{E}_{t}^{p s}\left[\left(C_{t+1}^{R}\right)^{-\sigma} \frac{e_{t+1}}{e_{t}}\right] .
\end{gathered}
$$

A microfoundation for the credit spread in the home bond Euler equation is developed in Cúrdia and Woodford (2016) and for the spread in the foreign bond equation in Menna and Tobal (2018). Similarly to the simplified model of subsection 2.1, the superscript $p s$ on the conditional expectation operator indicates that expectations of the private sector deviate from fully rational. The specific assumption here is that private agents, i.e. the Ricardian households that make financial decisions, assign a zero probability to the occurrence of a financial crisis on date $t=2$.

The technology is similar to the one in the simplified model of the previous subsection. The unit continuum of monopolistically competitive firms produce differentiated varieties of the domestic good using labour and imported input. The production function is CES with $\gamma>0$ being the cross-elasticity of substitution between labor and the imported input:

$$
Y_{t}(j)=\left(\alpha^{\frac{1}{\gamma}} N_{t}(j)^{\frac{\gamma-1}{\gamma}}+(1-\alpha)^{\frac{1}{\gamma}} M_{t}(j)^{\frac{\gamma-1}{\gamma}}\right)^{\frac{\gamma}{\gamma-1}},
$$

where $\alpha \in(0,1) ; N_{t}(j)$ is labor input; $M_{t}(j)$ is imported materials. All differentiated varieties are eventually repacked into the composite final nontradable goods by 
perfectly competitive repackers. The repacking technology is described by another CES aggregator with symmetric weights and the cross-elasticity of substitution between different varieties equal to $\theta>1$ :

$$
Y_{t}=\left(\int_{0}^{1} Y_{t}(j)^{\frac{\theta-1}{\theta}} d j\right)^{\frac{\theta}{\theta-1}}
$$

We consider two cases, where the cross-elasticity of substitution between labour and the imported input is either $\gamma \neq 1$ or $\gamma=1$, and in the latter case the production function (20) becomes equation (21):

$$
Y_{t}(j)=N_{t}(j)^{\alpha} M_{t}(j)^{1-\alpha}
$$

Equation (22) characterises the optimal mix of the two production inputs labour, $N_{t}$, and imported materials, $M_{t}$ - by a typical domestic firm that is consistent with the minimisation of production costs:

$$
\frac{\alpha}{1-\alpha}\left(\frac{M_{t}}{N_{t}}\right)=\left(\frac{w_{t}}{e_{t}}\right)^{\gamma} .
$$

Labour market clearing implies equation (23):

$$
N_{t}=(1-v) N_{t}^{R}+v N_{t}^{N R}
$$

By assumption, a fraction $1-\xi \in(0,1)$ of firms get the opportunity to reset their price on date $t=1$ whereas on all other dates all prices are fully flexible. Equation (24) characterises the optimal choice of date $t$ price by domestic producers of differentiated goods:

$p_{t}^{\text {flex }}= \begin{cases}\frac{\theta}{\theta-1}\left(\alpha w_{t}^{1-\gamma}+(1-\alpha) e_{t}^{1-\gamma}\right)^{\frac{1}{1-\gamma}}\left(1+s_{t}\right)^{\eta}, & \text { if } \gamma \neq 1 \\ \frac{\theta}{\theta-1}\left(\frac{w_{t}}{\alpha}\right)^{\alpha}\left(\frac{e_{t}}{1-\alpha}\right)^{1-\alpha}\left(1+s_{t}\right)^{\eta}, & \text { if } \gamma=1\end{cases}$

where $p_{t}^{\text {flex }}$ is the real price chosen by the firms that reset their prices on date $t$; $w_{t}$ is the real wage; $e_{t}$ is the real exchange rate; $s_{t}$ is the credit spread. A microfounded model, in which credit spread endogenously appears in the real marginal cost relationship, is developed in Cúrdia and Woodford (2016). In brief, the marginal cost of firms depends on the slope of the aggregate labour supply, which is the sum of labour supply curves of patient and impatient households. The labour supply of either type of workers depends on this type's marginal utility of consumption. Since in equilibrium, the marginal utility of consumption is not equalised between the patient and the impatient because of the credit spread, the difference in the marginal utility of consumption between the two types, which is a function of the credit spread, becomes a determinant of the aggregate labour supply and, hence, firms' marginal cost. 
Equation (25) is the definition of the aggregate price level:

$$
(1-\xi)\left(p_{t}^{\text {flex }}\right)^{1-\theta}+\xi\left(p_{t}^{\text {fix }}\right)^{1-\theta}=1,
$$

where $p_{t}^{f i x}$ is date $t$ real price for the product of firms that do not reset their prices on date $t$. As already mentioned, such firms, their fraction being $\xi$, are present on the market only on date $t=1$. Equation (26) becomes the definition of price inflation:

$$
1+\pi_{t}=\left((1-\xi)\left(\frac{p_{t}^{f l e x}}{p_{t}^{f i x}}\right)^{1-\theta}+\xi\right)^{\frac{1}{1-\theta}}
$$

Of course, in equilibrium, inflation is zero in all periods but $t=1$.

In each period, the economy receives a random endowment $X_{t}$ of internationally traded good, called 'oil.' The government is entitled to an exogenous share $\tau \in(0,1)$ ('tax') of oil revenue whereas households are entitled to the rest. Government spending $G_{t}$ that consists only of the domestic final good is financed by the government's oil revenues. Equation (27) becomes the government budget constraint:

$$
G_{t}+\beta e_{t} B_{t}^{g}=\tau e_{t} X_{t}+e_{t} B_{t-1}^{g}
$$

Households purchase imported materials and re-sell them to domestic firms along with their labour. Aggregating across households and the government yields the balance of payments identity (28), where $B_{t}$ and $B_{t}^{g}$ are private and public foreign bond holdings, respectively, and $X_{t}$ is oil export revenue:

$$
M_{t}+\beta\left(B_{t}+B_{t}^{g}\right)=X_{t}+B_{t-1}+B_{t-1}^{g} .
$$

Relationship (29) is the economy's resource constraint:

$$
Y_{t}=(1-v) C_{t}^{R}+v C_{t}^{N R}+G_{t}
$$

In the analysis below, we consider two different fiscal frameworks. First, we consider a balanced budget arrangement where the government spends all its current revenue. Second, we consider a so-called structural balance fiscal rule (30) that prescribes the government to spend only a permanent part of its revenues:

$$
G_{t}=(1-\beta)\left[e_{t} B_{t}^{g}+\sum_{k=0}^{\infty} \beta^{k} \mathbb{E}_{t} X_{t+k}\right]
$$

It implies that, in the absence of shocks, the chosen time path of government consumption is flat. In other words, the government smoothes its consumption over time. 
In the rest of the paper we analyse the optimal response of monetary and macroprudential policies to two disturbances: a credit growth shock and an oil price shock. We assume, based on the evidence reported in Shousha (2016), that commodity booms produce credit booms in commodity-exporting economies. To the extent that credit growth helps predict financial crises (Schularick and Taylor, 2012; Gourinchas and Obstfeld, 2012), commodity booms potentially make these economies more vulnerable to financial instability in the future. Technically, we add the oil endowment as an additional input in the credit growth equation.

A generic scenario that we analyse is the following. Until date $t=0$ the economy rests in the original steady state with no financial frictions. On date $t=1$ an unanticipated shock arrives. There is nominal price rigidity on date $t=1$ : only fraction $1-\xi$ of domestic firms can reset their price, whereas fraction $\xi$ of them keep selling at the price that was in effect on date $t=0$. As was already mentioned, financial frictions in the form of credit spread are present only on date $t=1$ as well. Starting from date $t=2$, goods prices are flexible, and financial frictions evaporate, with no other shocks hitting the economy ever. The economy finds itself in a new steady state where it remains forever. The new steady state reached on date $t=2$ can be either good or bad. The bad steady state is associated with a financial crisis that can occur on date $t=2$. In other words, a financial crisis can happen in the long run as a consequence of excessive credit growth in the short run on date $t=1$. Unlike in Cúrdia and Woodford (2016), credit does not appear as a separate endogenous variable in our model. Similarly to Aikman et al. (2018), we take a pragmatic minimalist approach, namely, we model credit growth and the probability of crisis on date $t=2$ outside of the main macroeconomic framework.

As in Aikman et al. (2018), we assume that the probability of a financial crisis on date $t=2$ from the perspective of date $t=1, \gamma_{1}$, positively depends on the credit growth on date $t=1, L_{1}$, and negatively on the degree of tightness of macroprudential policy, which is labeled as the $\mathrm{CCyB}$ in that paper:

$$
\gamma_{1}=\frac{\exp \left(h_{0}+h_{L} L_{1}+h_{k} k_{1}\right)}{1+\exp \left(h_{0}+h_{L} L_{1}+h_{k} k_{1}\right)}, \quad h_{L}>0, \quad h_{k}<0 .
$$

The excessive credit growth makes the economy vulnerable to financial instability in the future. Capital buffers applied in advance make the financial system more resilient and, thus, reduce the probability of a crisis. The credit growth on date $t=1$ negatively depends on the policy rate, $i_{1}$, and the credit spread, $s_{1}$. The credit spread is linked to the stance of the macroprudential policy expressed as a CCyB as $s_{1}=\psi_{k} k_{1}, \psi_{k}>0$. An increase in both variables makes credit more expensive and, thus, decelerates credit growth on date 1. In addition to these two determinants of the credit growth, we introduce the commodity price as a factor specific to commodityexporting economies. The postulated credit growth equation is 


$$
L_{1}=\phi_{0}+\phi_{i} i_{1}+\phi_{S} s_{1}+\phi_{X} \hat{X}_{1}+\xi_{1}^{L}
$$

where $\xi_{1}^{L}$ is an exogenous credit growth shock and $\hat{X}_{1} \equiv\left(X_{1}-X_{0}\right) / X_{0}$. Parameters $\phi_{0}>0, \phi_{i}<0, \phi_{s}<0$, and $\phi_{X}>0$ in the credit growth equation as well as $h_{0}, h_{L}$, and $h_{k}$ in the crisis probability equation are calibrated based on existing empirical estimates in the literature (Ajello et al., 2019; Aikman et al., 2018).

The relationships between the crisis probability on date $t=2$, on the one hand, and the credit growth and the oil price growth on date $t=1$, on the other hand, are shown in Figures 1 and 2, respectively. Different lines on the graph correspond to different values of the CCyB parameter, $k_{1}$.

Figure 1. Impulse responses of crisis probability to a credit growth shock on date $t=1$ : small open economy with a structural balance fiscal rule and non-Ricardian households
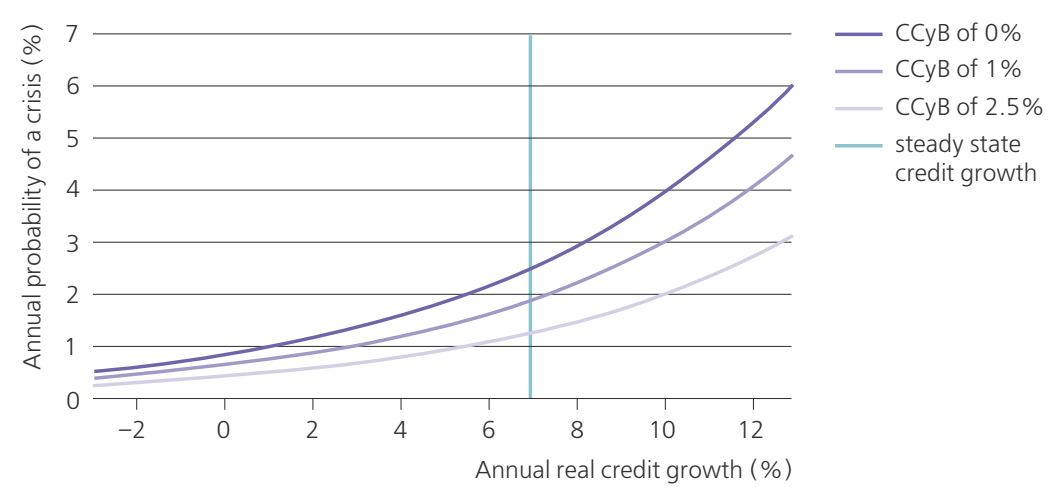

Figure 2. Impulse responses of crisis probability to an oil price shock on date $t=1$ : small open economy with a structural balance fiscal rule and non-Ricardian households
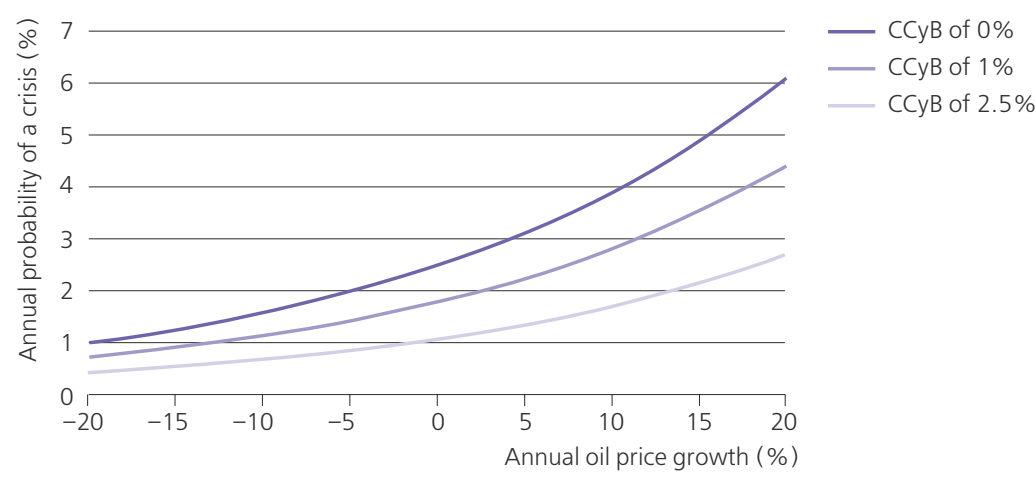

The notion of the bad steady state is a simplification. The aftermath of a typical financial crisis is described as a period of time during which the output is below the potential followed by the return to normal growth along the long-run trend. 
In our model, the difference in output between the good and the bad date $t=2$ steady states should be interpreted in the present value terms.

Following Ajello et al. (2019) and Aikman et al. (2018), we assume that private agents are myopic and underestimate the likelihood of financial crisis on date $t=2$. They assign zero probability to the crisis state. The government is rational and assigns probability $\gamma_{1}$ to the crisis state on date $t=2$.

\subsection{Equilibrium and solution}

The equilibrium in the model is characterised by the following set of equations: non-Ricardian households' one-period budget constraint (15), non-Ricardian and Ricardian households' labour supply equations (16) and (17), home and foreign bonds Euler equations (18) and (19), production function (20) and (21), domestic producers' optimal choice of the production inputs (22), labour market clearing (23), domestic producers' optimal choice of the price (24), definition of the aggregate price level (25), definition of inflation (26), government budget constraint (27), balance of payments identity (28), resource constraint (29), and a fiscal rule (30).

Until $t=1$ the economy rests in a deterministic steady state with flexible prices, no financial frictions, and no shocks anticipated. The initial symmetric steady state is described by the following system of equations evaluated at date $t=0$ and $s_{0}=0$ : non-Ricardian households' one-period budget constraint (15), non-Ricardian and Ricardian households' labour supply equations (16) and (17), production function (20) and (21), domestic producers' optimal choice of the production inputs (22), labour market clearing (23), domestic producers' optimal choice of the price (24), government budget constraint (27), balance of payments identity (28), and a resource constraint (29). This is a closed system of ten equations in ten unknowns: $N_{0}, N_{0}^{R}, N_{0}^{N R}, M_{0}, Y_{0}, C_{0}^{R}, C_{0}^{N R}, G_{0}, w_{0}$, and $e_{0}$, for given values of $X_{0}, B_{0}$, and $B_{0}^{g}$.

The model is solved by log-linearising equilibrium equations around the steady state at $t=0$. By assumption, all unanticipated shocks materialise only on date $t=1$. Nominal price rigidity and financial market frictions are also present only on date $t=1$. It follows that the economy will find itself in a new steady state on date $t=2$ and remain there forever. For periods $t=1$ and $t \geq 2$, the equilibrium is described by a system of log-linearised equations (37) - (60) in the Appendix.

\subsection{Calibration}

Benchmark parameter values are shown in Table 1.

Our calibration of the New Keynesian small open economy is standard. Our calibration of the credit block of the model mostly follows Aikman et al. (2018) because we are interested in comparing those authors' results for a closed economy with our results for a small open economy. 
Table 1. Benchmark parameter values

\begin{tabular}{|c|c|c|}
\hline Parameter & Value & Description \\
\hline \multicolumn{3}{|c|}{ Initial steady state } \\
\hline$B_{0}$ & 10 & Net foreign assets of the private sector (in levels) \\
\hline \multicolumn{3}{|c|}{ Standard parameters } \\
\hline$\beta$ & 0.97 & Time discount \\
\hline$\alpha$ & 0.8 & Share of labour in production \\
\hline$\gamma$ & 1 or 0.7 & Cross-elasticity of substitution between labour and materials \\
\hline$\sigma$ & $1 / 0.6$ & $\begin{array}{l}\text { Relative risk aversion coefficient (Note: This is the reciprocal } \\
\text { of } \sigma \text { in original Aikman et al. (2018) model.) }\end{array}$ \\
\hline$\lambda$ & 0.05 & Weight on output stabilisation \\
\hline$i^{*}$ & $1 / \beta-1$ & Long-run nominal natural rate of interest \\
\hline \multicolumn{3}{|c|}{ Additional 'micro' parameters } \\
\hline$\xi$ & 0.65 & Fraction of firms that do not reset prices on date 1 \\
\hline$\phi$ & 0.1 & Inverse Frisch elasticity of labour supply \\
\hline$\theta$ & 6 & $\begin{array}{l}\text { Cross-elasticity of substitutions between different varieties } \\
\text { of home goods }\end{array}$ \\
\hline$\psi$ & 1 & Labour disutility parameter \\
\hline$v$ & 0.5 & Fraction of non-Ricardian households \\
\hline \multicolumn{3}{|c|}{ CCyB transmission mechanism } \\
\hline$\psi_{k}$ & 0.2 & Effect of CCyB on credit spreads \\
\hline$\omega$ & 1 & Effect of spreads on the IS curve \\
\hline$\eta$ & 1 or 0.5 & Semi-elasticity of marginal cost to credit spread \\
\hline \multicolumn{3}{|c|}{ Oil and government } \\
\hline$X_{0}$ & 2 & Oil exports on date 0 (in levels) \\
\hline$X_{2}$ & 0 & $\begin{array}{l}\text { Rationally expected date } 2 \text { oil exports } \\
\text { (in log-deviations from } X_{0} \text { ) }\end{array}$ \\
\hline$B_{0}^{g}$ & 10 & NFA held by government \\
\hline$\tau$ & 0.5 & Tax rate applied to oil export revenues \\
\hline \multicolumn{3}{|c|}{ Financial condition equation } \\
\hline$\phi_{0}$ & 0.21 & Average real credit growth \\
\hline$\phi_{i}$ & -1.5 & Coefficient on interest rates \\
\hline$\phi_{s}$ & -6 & Coefficient on spreads \\
\hline$\phi_{X}$ & 0.3 & Coefficient on oil price growth \\
\hline \multicolumn{3}{|c|}{ Crisis probability equation } \\
\hline$h_{L}$ & 5.18 & Sensitivity of crisis probability w.r.t. credit growth, $L_{t}$ \\
\hline$h_{k}$ & -27.8 & Sensitivity of crisis probability w.r.t. ССyВ, $k_{t}$ \\
\hline$h_{0}$ & $-1.7+0.11 h_{k}$ & Constant Period 2 parameters \\
\hline$\delta$ & -0.041 & Log-deviation of output from target in crisis state on date 2 \\
\hline$\zeta$ & 0 or 2 & Policymaker's extra weight on crisis avoidance \\
\hline
\end{tabular}

The value of the private net foreign asset holdings, $B_{0}$, is set equal to 10 .

The time discount, $\beta$, is calibrated at 0.97. As in Aikman et al. (2018), the 'length' of period $t=1$, i.e. of the short run, is about three years in our exercise.

The share of labour in the production of final domestic goods, $\alpha$, is set equal to 0.8 , which implies that the share of imports is 0.2 . 
For the cross-elasticity of labour and imported inputs in the production of domestic goods, $\gamma$, we try two values. The first one is 1 , which is standard and corresponds to the Cobb-Douglas production technology. The other one is 0.7, which implies a certain degree of complementarity between the two inputs.

The relative risk aversion parameter, $\sigma$, is usually calibrated in the range between 1 and 4. Aikman et al. (2018) set the slope of the New Keynesian IS curve (the Euler equation), i.e. the reciprocal of the relative risk aversion coefficient, equal to 0.6 . To make our findings comparable to theirs, we choose the value $1 / 0.6$ for the relative risk aversion coefficient, which is in the range of consensus values.

The weight on the output gap in the loss function of the central bank, $\lambda$, is set equal to 0.05 , which is standard in the monetary economics literature (Woodford, 2003).

The long run equilibrium level of interest, $i^{*}$, is related to the subjective time discount factor: $i^{*}=1 / \beta-1$.

The inverse Frisch elasticity of labour supply is set equal to 0.1 , which implies that the individual labour supply is rather elastic with respect to wages. Although not supported by microeconomic evidence, this calibration is standard (Woodford, 2003).

The fraction of sellers that do not change their price on date $t=1, \xi$, is set equal to 0.65 . In combination with the inverse Frisch elasticity parameter, $\phi$, and the time discount factor, $\beta$, this value yields the slope of the New Keynesian Phillips Curve close to 1, which is in line with the calibration of Aikman et al. (2018).

The cross-elasticity of substitution between different varieties of the final home goods, $\theta$, is set equal to 6 . This corresponds to the steady state value of the markup of $6 /(6-1)=1.2$, or $20 \%$.

The labour disutility parameter, $\psi$, is set equal to 1 without loss of generality.

The fraction of non-Ricardian households, $v$, is set equal to 0.5 , as in Medina and Soto (2016).

The elasticity of the credit spread to the $\mathrm{CCyB}$ parameter, $\psi_{k}$, is calibrated at $\psi_{k}=0.2$ based on empirical evidence reported in Aikman et al. (2018).

The semi-elasticity of marginal cost, $\eta$, is assigned two alternative values, 1 and 0.5 . In the first case, the pass-through of higher credit spreads into marginal costs and goods prices is complete, whereas in the second case it is only partial. With no consensus on the relationship between credit spreads and marginal costs, we believe that our approach is reasonable. The value of 1 , in combination with the fraction of non-optimising firms parameter $\xi$, yields the elasticity of inflation with respect to the credit spread implied by the New Keynesian Phillips Curve close to 0.4, which is the calibration in Aikman et al. (2018) obtained from empirical evidence.

The export revenue generated by oil endowment in the initial steady state, $X_{0}$, in levels, is chosen rather arbitrary at $X_{0}=2$. It is assumed that following a temporary shock on date $t=1$, the oil exports revenue is back to the pre-shock level, $\hat{X}_{2}=0$, in log-deviations from $X_{0}$. 
The government holdings of foreign bonds in the initial steady state are set, rather arbitrarily, equal to $B_{0}^{g}=10$.

The tax rate for commodity exports is set equal to $\tau=0.5$.

The parameters of the financial condition equation and the crisis probability relationship are borrowed from Aikman et al. (2018). The semi-elasticities of credit growth to interest rate and credit spread are set equal to $\phi_{i}=-1.5$ and $\phi_{s}=-6$, respectively. These values are based on empirical evidence on the sensitivity of credit growth to interest rates and spreads. In addition, the elasticity of credit growth to the oil price growth, $\phi_{X}$, is calibrated based on SVAR evidence in Shousha (2016) and is set equal to $\phi_{X}=0.3$. The average credit growth over three-year period is set equal to $\phi_{0}=0.21$ or $21 \%$, as in Aikman et al. (2018). The parameters of the crisis probability relationship (31), are set equal to $h_{L}=5.18, h_{k}=-27.8$, and $h_{0}=-1.7+0.11 h_{k}$. These parameter values are estimated in cross-country panel logit regressions similar to Gourinchas and Obstfeld (2012), where credit growth serves as a major predictor of financial crisis at a three-year horizon.

Finally, the output loss in the crisis state is set equal to $\delta=-0.041$ or $-4.1 \%$ whereas the extra weight on the crisis avoidance, $\zeta$, takes a value of 0 or 2 , as in Aikman et al. (2018).

\section{Results}

\subsection{Small open economy without a fiscal sector or non-Ricardian households}

First, we consider a special case of the general model without a fiscal sector or non-Ricardian households: $v=0, G_{t}=0, \tau=0, B_{t}^{g}=0$. The purpose of this exercise is to gain some intuition behind more general results in a minimalist environment. We focus on two main structural shocks of interest: (i) a credit growth shock on date $t=1$ unrelated to a commodity boom similar to Aikman et al. (2018) but in the small open economy framework; (ii) credit growth induced by a commodity boom on date $t=1$ that we model by making $\hat{X}_{1}$ an additional input in the credit growth equation (32) and calibrating the elasticity based on the SVAR evidence reported in Shousha (2016).

Figure 3 shows impulse responses of endogenous variables of the model to a temporary $10 \%$ increase in the price of oil on date $t=1$ assuming that the stance of monetary and macroprudential policies is neutral. Given that the shock is shortlasting, it induces a smoothing response: a big fraction of the oil bonanza is saved through accumulation of foreign bond holdings. As a result, the economy can afford to purchase more imported materials and enjoy more leisure in all periods starting from date $t=1$. A rise in the final goods output is accompanied by the growth in real wages and real appreciation. The response of the economy to the shock is optimal, up to distortions caused by the monopoly power of domestic 
producers. The responses of the natural level of output, exchange rate, etc. coincide with responses of their counterparts. Despite date $t=1$ sticky prices, the optimal adjustment to the shock is achieved due to the accommodating response of the exchange rate. To the extent, though, that commodity booms tend to trigger credit booms in emerging market economies (Shousha, 2016), this will translate into a higher probability of financial crisis on date $t=2$.

Figure 3. Impulse responses of endogenous variables to a temporary $10 \%$ increase in the price of oil on date $t=1$ : small open economy without a fiscal sector or non-Ricardian households
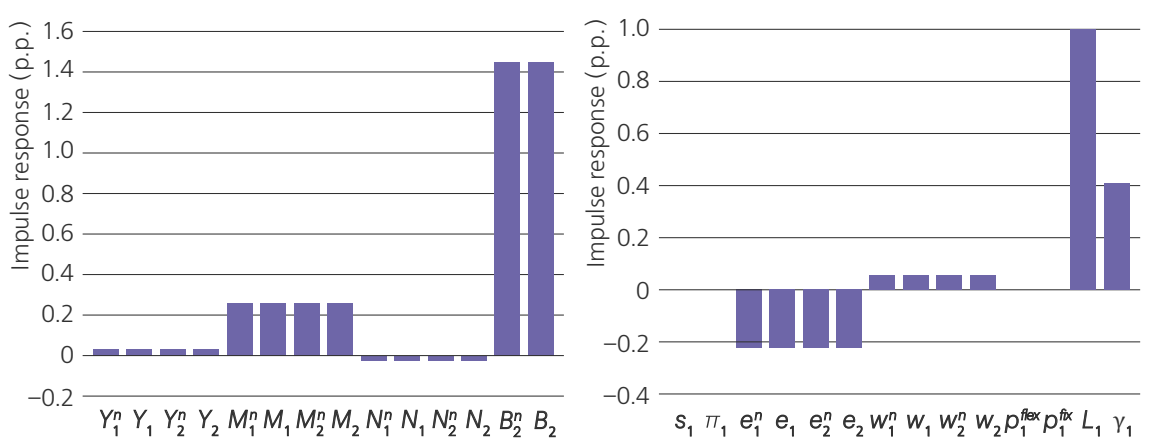

Figures 4 and 5 show impulse responses of endogenous variables to a monetary shock and a macroprudential policy shock, labelled as a CCyB shock. Both shocks adversely affect aggregate demand and produce a recession on date $t=1$. The effect of the monetary policy shock is deflationary whereas that of the CCyB shock is weakly inflationary due to the pass-through of higher credit spreads into firms' marginal costs and goods prices. Both shocks have a negative effect on the credit growth and, therefore, reduce the likelihood of financial instability on date $t=2$.

Figure 4. Impulse responses of endogenous variables to a 1 p.p. monetary policy shock on date $t=1$ : small open economy without a fiscal sector or non-Ricardian households
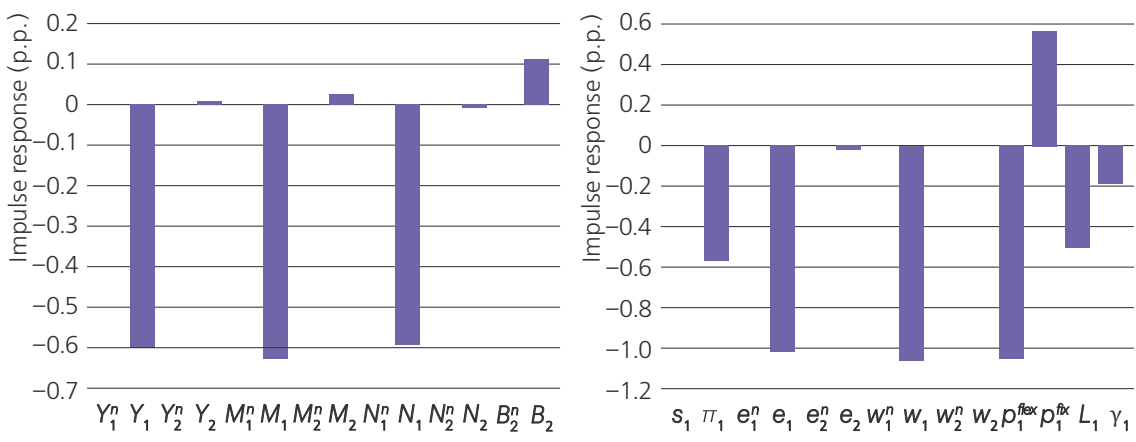
Figure 5. Impulse responses of endogenous variables to a 1 p.p. CCyB shock on date $t=1$ : small open economy without a fiscal sector or non-Ricardian households
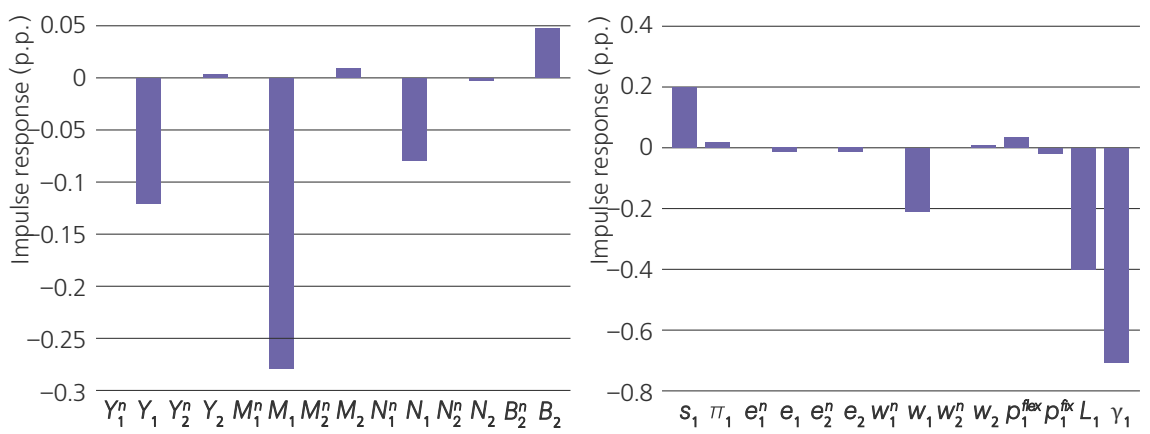

Figure 6. Impulse responses of endogenous variables to a 1 p.p.

monetary policy shock on date $t=1$ : closed economy (financial autarky)

without a fiscal sector or non-Ricardian households
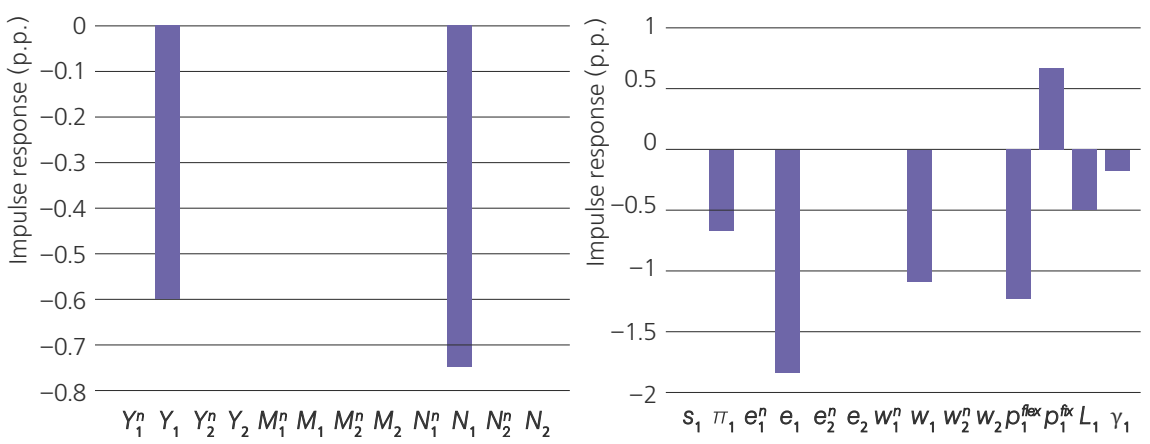

Figure 7. Impulse responses of endogenous variables to a 1 p.p. CCyB shock on date $t=1$ : closed economy (financial autarky) without a fiscal sector or non-Ricardian households
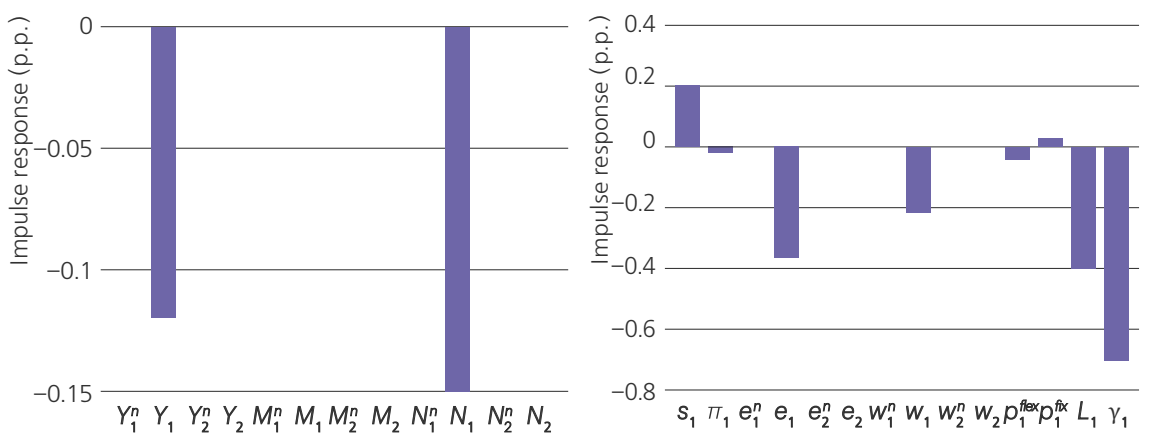

Figures 6 and 7 show impulse responses of endogenous variables to a monetary and a macroprudential policy shock in a closed economy with the same characteristics as the small open economy model being analysed. The closed economy (financial autarky, to be more precise) does not trade in financial assets 
with the rest of the world. This implies that the contractionary effect of both shocks on the real price of the imported inputs must be more pronounced as the economy with no opportunity to save internationally has to utilise the entire amount of imported inputs received in exchange for exported oil. As in the small open economy case, both policy disturbances decelerate credit growth on date $t=1$ and reduce the probability of a financial crisis on date $t=2$.

The main exercise of this paper involves finding optimal responses of monetary and macroprudential policies with regard to two different structural shocks, one at a time, namely, (i) a credit growth shock unrelated to a commodity boom and (ii) a spike in credit growth triggered by a commodity boom. Figures 8 and 9 show date $t=1$ optimal responses of $\mathrm{CCyB}$ and policy rate to real credit growth shocks of different size - the disturbance $\xi_{1}^{L}$ in equation (32) - for the small open economy and the closed economy. The pattern for the closed economy is similar to the results of Aikman et al. (2018): in response to a credit growth shock CCyB tightening should be accompanied by some monetary easing. It turns out that this is not necessarily the case for a small open economy. Indeed, as Figure 8 suggests, the optimal policy mix requires a well-pronounced $\mathrm{CCyB}$ tightening backed by some moderate-to-weak monetary tightening. If a credit boom is brought on the back of a commodity boom, this pattern survives, as Figure 10 demonstrates.

Figure 8. Optimal responses of monetary and macroprudential policies to a credit growth shock on date $t=1$ : small open economy without a fiscal sector or non-Ricardian households, $\eta=1$
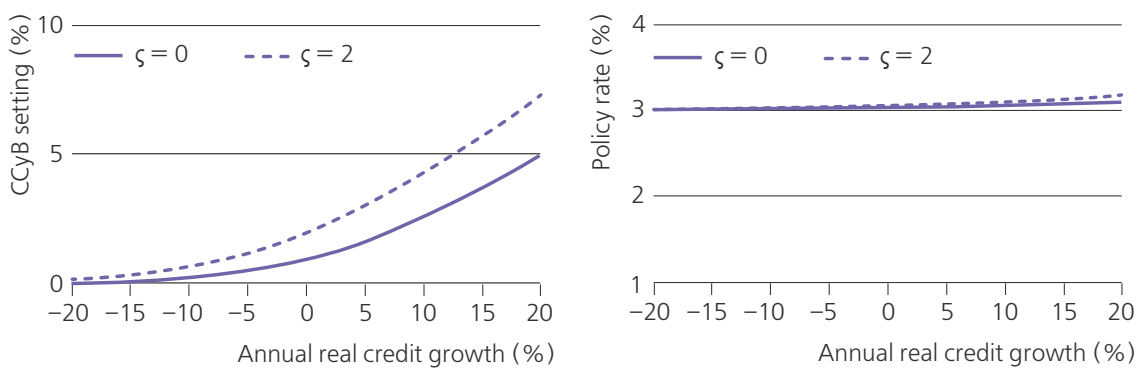

Figure 9. Optimal responses of monetary and macroprudential policies to a credit growth shock on date $t=1$ : closed economy without a fiscal sector or non-Ricardian households, $\eta=1$
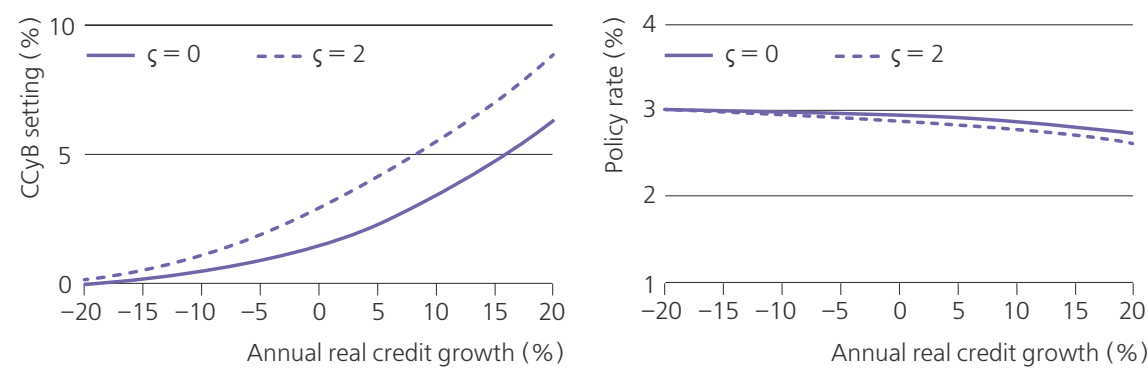
Figure 10. Optimal responses of monetary and macroprudential policies to credit growth induced by an oil price shock on date $t=1$ : small open economy without a fiscal sector or non-Ricardian households, $\eta=1$
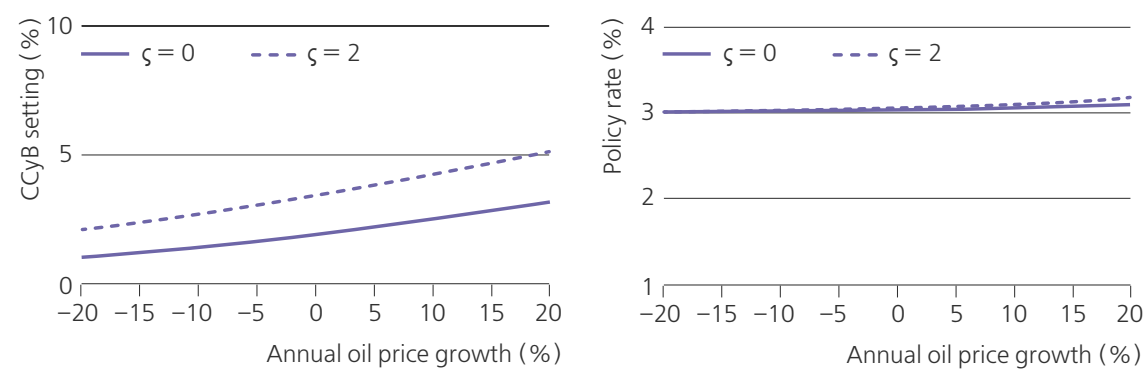

The key parameter that determines whether macroprudential tightening should be accompanied by monetary easing or, rather, tightening is $\eta$, the degree of pass-through of credit spreads into marginal costs in equation (24). It would be more appropriate to say, though, that monetary policy should remain roughly neutral according to Figures 8 and 10. Figures 8, 9, and 10 were obtained for $\eta=1$, which means that a rise in the credit spread by 1 p.p. fully passes through to the price of producers that have the opportunity to reset their price on date $t=1$, thus making a sizable contribution to date $t=1$ inflation. It is conceivable though that the pass-through of credit spreads into producer prices be far from complete. Figures 11, 12, and 13 show optimal combinations of CCyB and the policy rate for $\eta=0.5$. We now observe that, both in a small open economy and a closed economy (financial autarky, to be more precise), the optimal policy mix requires that macroprudential tightening be accompanied by monetary easing. Below we provide some explanation of why the degree of the credit spread passthrough matters, after which we turn to the analysis of a small open economy with fiscal sector.

Figure 11. Optimal responses of monetary and macroprudential policies to a credit growth shock on date $t=1$ : small open economy without a fiscal sector or non-Ricardian households, $\eta=0.5$
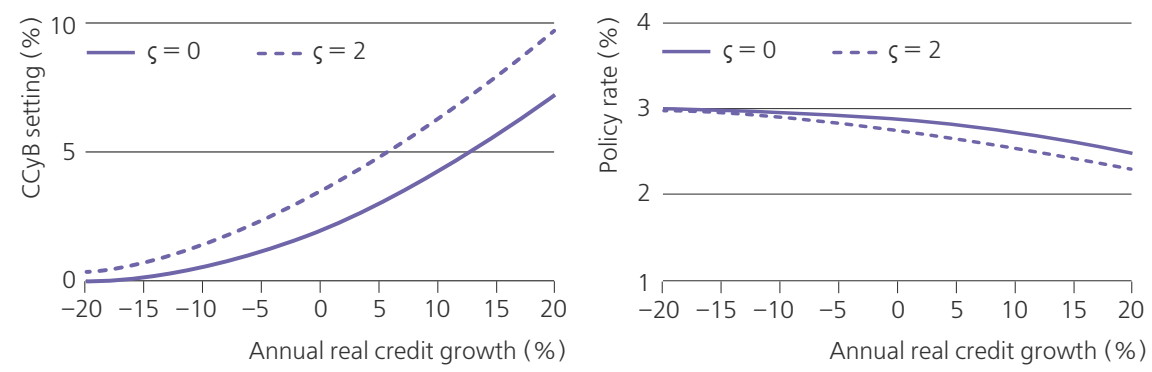
Figure 12. Optimal responses of monetary and macroprudential policies to a credit growth shock on date $t=1$ : closed economy without a fiscal sector or non-Ricardian households, $\eta=0.5$
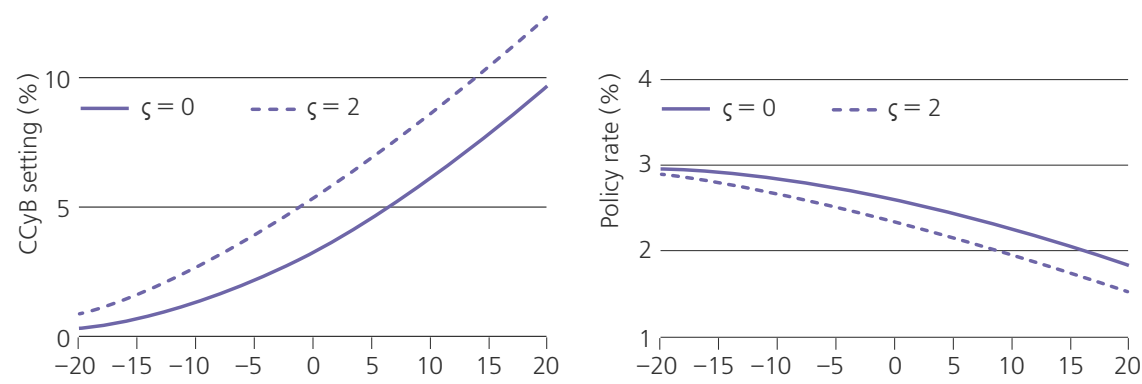

Figure 13. Optimal responses of monetary and macroprudential policies to credit growth induced by an oil price shock on date $t=1$ : small open economy without a fiscal sector or non-Ricardian households, $\eta=0.5$
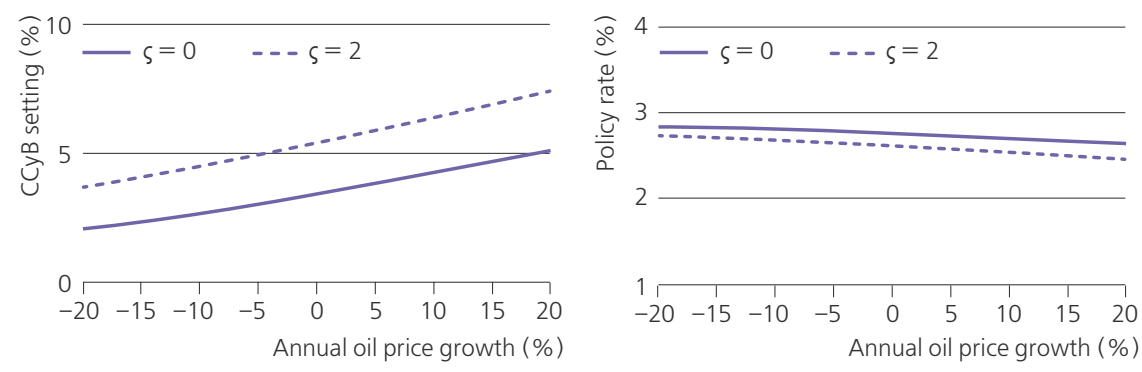

For illustration purposes only, we make a simplifying assumption that the inverse Frisch elasticity of labour supply parameter, $\phi$, equals 0 (in our baseline calibration it is set equal to 0.1 ). It is straightforward to show that date $t=1$ equilibrium values of output and inflation are

$$
\begin{gathered}
\hat{Y}_{1}=\frac{-\left(\frac{\alpha}{1-\alpha}+\frac{\beta}{\sigma}\right) i_{1}-\left(\frac{\alpha^{2}}{1-\alpha}+\beta\left(\alpha+\frac{1}{\sigma}\right)\right) s_{1}}{1+\alpha \sigma+\frac{\alpha^{2} \sigma}{1-\alpha}} \\
\pi_{1}=\frac{1-\xi}{\xi}\left(-i_{1}+(\eta-\alpha) s_{1}\right)
\end{gathered}
$$

where we assume that $\hat{X}_{1}=\hat{X}_{2}=0$. Relationships (33) and (34) imply that the effect of the policy rate, $i_{1}$, on date 1 output and inflation is always negative: an increase in the policy rate reduces output and produces deflation. The effect of tighter $\mathrm{CCyB}$ on output, through higher credit spread $s_{1}$, is also negative, but the sign of its effect on inflation is determined by the sign of the factor $(\eta-\alpha)$. A sufficiently high value of $\eta$, i.e. $\eta>\alpha$, means that the pass-through of credit spreads into marginal cost and inflation is strong. Calibrated parameters $\phi_{s}, \phi_{i}, \psi_{k}, h_{L}$, and $h_{k}$ 
in (32), (31), and $s_{1}=\psi_{k} k_{1}$, which are based on empirical evidence, suggest that macroprudential policy in general and $\mathrm{CCyB}$ in particular are more effective against excessive credit growth and financial instability than monetary policy. Macroprudential policy should therefore primarily target financial stability on date $t=2$ by curbing unwanted credit growth on date $t=1$. Given that $\eta>\alpha$, tighter macroprudential policy is inflationary. Furthermore, it reduces output on date $t=1$. Some monetary easing would be able to make up for a decline in output but only at the cost of accelerating inflation even further. Provided that the weight on the output gap in the policymaker's loss function, $\lambda$, is much lower than the weight on the inflation under standard calibration (by the factor of 20), higher inflation on date 1 cannot be viewed as acceptable, and therefore monetary policy should remain roughly at the neutral stance. If, instead, the pass-through of credit spreads into marginal cost and prices is far enough from complete, the outcome of macroprudential tightening is a decline in both output and inflation. In this situation, monetary policy intervention is more than welcome: some monetary easing would bring date $t=1$ inflation and output closer to targeted values without much harm in terms of unwanted credit growth and resulting financial instability.

The last finding contrasts with the result derived in Aikman et al. (2018) for closed economy that macroprudential tightening aiming to curb excessive credit growth should always be accompanied by some monetary easing that compensates for a recessionary and deflationary impact of the macroprudential policy intervention. If we impose the financial autarky assumption in our simple model, i.e. $B_{t} \equiv 0$, the outcome will be

$$
\begin{gathered}
\hat{Y}_{1}=-\frac{1}{\sigma}\left(i_{1}+s_{1}\right), \\
\frac{\xi}{1-\xi} \pi_{1}=-\left(\frac{1-\alpha}{\alpha \sigma}+1\right) i_{1}-\left(\frac{1-\alpha}{\alpha \sigma}+1-\eta\right) s_{1} .
\end{gathered}
$$

Given that $\eta \leq 1$, equations (35) and (36) imply that the effect of tightening of either policy leads to lower output and deflation. This suggests that when macroprudential policy tightens, some monetary easing is always welcome.

It is worth mentioning that we remain agnostic with regard to the origins and the degree of pass-through of the credit spread to the prices and therefore consider a range possible parameter values. In the original Cúrdia and Woodford (2016) model, it is the difference in marginal disutility of labor between borrowers and savers, which is a consequence of the difference in marginal utility of consumption, that gives rise to the appearance of credit spread in the Phillips curve equation. One could imagine a different framework where firms borrow from banks and credit spread becomes part of firms' marginal cost.

It is remarkable that if the marginal cost is not sensitive to the credit spread, i.e. if $\eta=0$, then in a closed economy, the trade-off between achieving financial stability 
in the longer term and output loss in the shorter term disappears: according to equation (35), an increase in the credit spread can be offset by a reduction in the policy rate of an equal size, so that output and inflation are unaffected. This is not the case in a small open economy where the trade-off appears for all values of the pass-through parameter $\eta$, including $\eta=0$.

\subsection{Small open economy with non-Ricardian households and fiscal sector}

We now examine optimal combinations of monetary and macroprudential policies in a small open economy with a fiscal sector. In what follows, we consider two fiscal arrangements, one at a time: (i) one with a balanced budget in every period and (ii) the other with the structural balance fiscal rule. Recalling equation (30), the structural balance arrangement implies that the government spends only the 'permanent' part of its revenue, i.e. the fraction $1-\beta$ of the sum of the present value of all future export revenues and foreign bond holdings of the public sector. For simplicity, we assume that the oil rent and the interest income on foreign bonds are the only sources of revenue for the government. It follows that, under such an arrangement, temporary shocks in the price of oil should induce permanent changes in government spending of a smaller size. Only a fraction of temporary oil revenue surplus will be allocated to the current period's spending whereas the rest is saved through the accumulation of foreign assets (risk-free bonds).

Figures 14 and 15 show the optimal responses of macroprudential and monetary policies to credit growth shocks unrelated to commodity booms for the structural balance fiscal rule and two different values of $\eta$. One can see that both quantitatively and qualitatively the optimal responses are similar to those for the simpler model of subsection 3.1: for $\eta=1$, macroprudential policy tightens while monetary policy is about neutral; for $\eta=0.5$, macroprudential policy tightens while monetary policy loosens.

Figure 14. Optimal responses of monetary and macroprudential policies to a credit growth shock on date $t=1$ : small open economy with a structural balance fiscal rule and non-Ricardian households, $\eta=1$
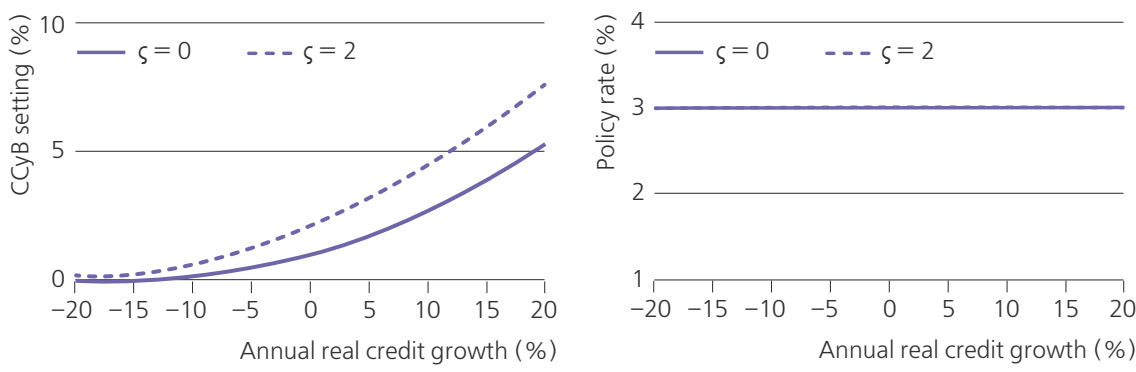
Figure 15. Optimal responses of monetary and macroprudential policies to a credit growth shock on date $t=1$ : small open economy with a structural balance fiscal rule and non-Ricardian households, $\eta=0.5$
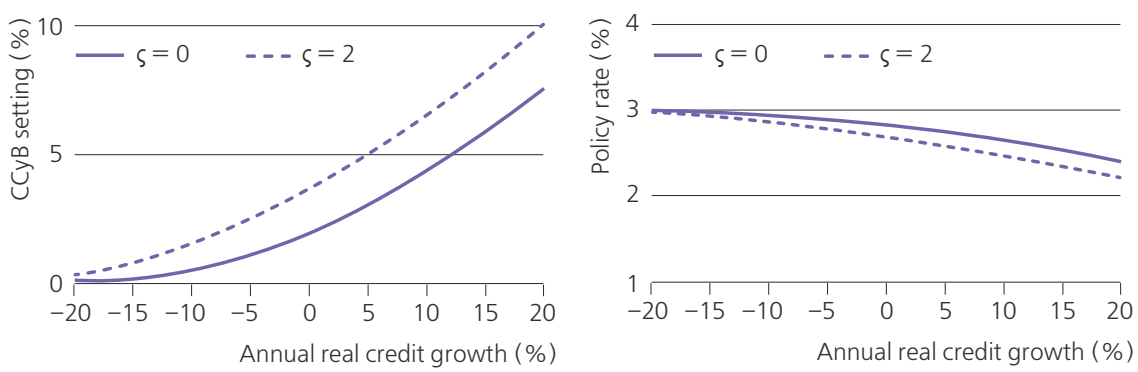

This pattern barely changes for the case shown in Figures 16 and 17 where the structural balance fiscal rule is replaced with the balanced budget in every period.

Figure 16. Optimal responses of monetary and macroprudential policies to a credit growth shock on date $t=1$ : small open economy with a balanced budget fiscal rule and non-Ricardian households, $\eta=1$
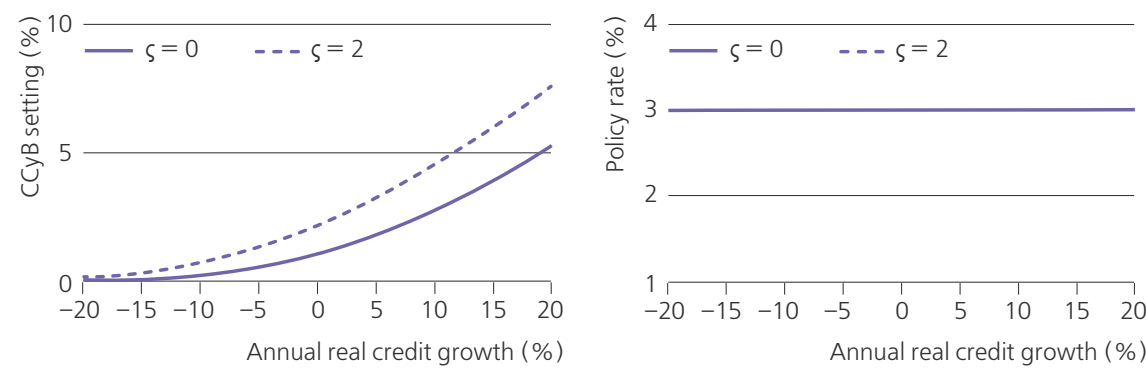

Figure 17. Optimal responses of monetary and macroprudential policies to a credit growth shock on date $t=1$ : small open economy with a balanced budget fiscal rule and non-Ricardian households, $\eta=0.5$
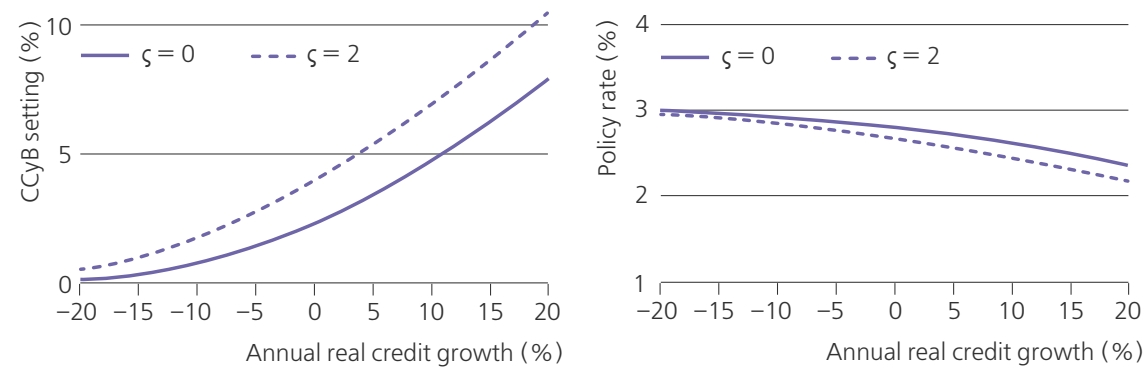

We now turn to the analysis of optimal policy response to date $t=1$ oil price shock that also triggers a credit boom on date $t=1$. Figures 18 and 19 show the optimal responses of macroprudential and monetary policies for different values of the shock to the price of oil on date $t=1$, assuming that the structural balance 
budget rule is in place. The pattern of the optimal macroprudential policy reaction is as expected: the response is positive and grows with the size of the shock. In contrast with the credit growth shock unrelated to the price of oil, the optimal monetary policy response implies loosening (i.e. $i_{1}$ is below the steady state value of $3 \%$ ) for negative values of the oil price shock and tightening (above 3\%) for positive values of the shock. The optimal response of macroprudential policy is more aggressive if $\eta=0.5$ than if $\eta=1$. If $\eta$ changes from 1 to 0.5 , monetary policy response becomes somewhat more pronounced for negative realisations of the oil price shock and less pronounced for positive realisations. The natural question is: Why does the optimal response of monetary policy differ so dramatically for the two shocks?

Figure 20 shows impulse responses of endogenous variables of the model to a $10 \%$ increase in the price of oil on date $t=1$. Superscript $n$ denotes the natural level of the respective real variable, i.e. its equilibrium value under flexible nominal prices. The model with non-Ricardian households can be viewed, in a sense, as being half-way between the closed economy model where no agents except the government have access to the international bond market and a small open economy of subsection 3.1 with Ricardian households only where everyone has access to the international bond market (intermediated by domestic banks).

Figure 18. Optimal responses of monetary and macroprudential policies to credit growth induced by an oil price shock on date $t=1$ : small open economy with a structural balance fiscal rule and non-Ricardian households, $\eta=1$
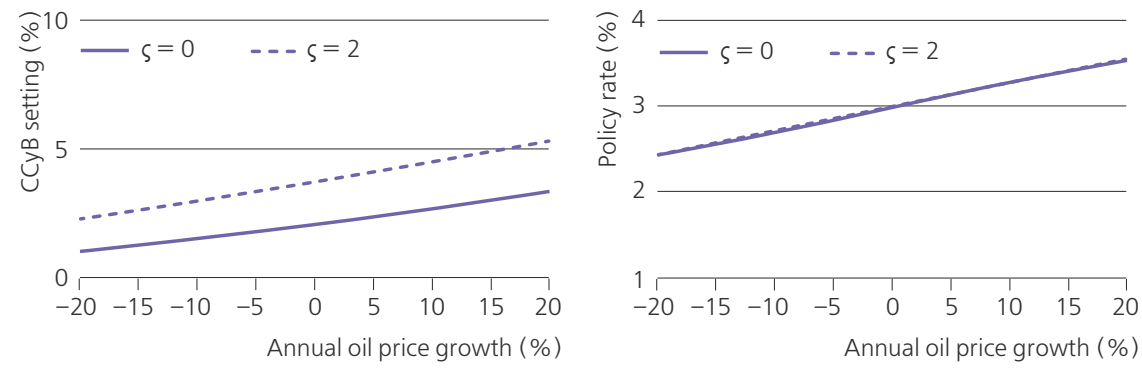

Figure 19. Optimal responses of monetary and macroprudential policies to credit growth induced by an oil price shock on date $t=1$ : small open economy with a structural balance fiscal rule and non-Ricardian households, $\eta=0.5$
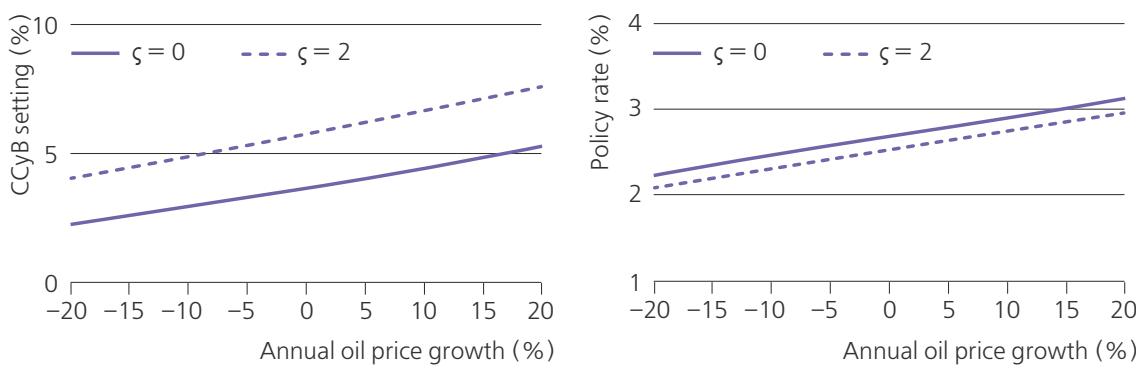
Figure 20. Impulse responses of endogenous variables to a $10 \%$ oil price shock on date $t=1$ : small open economy with a structural balance fiscal rule and non-Ricardian households
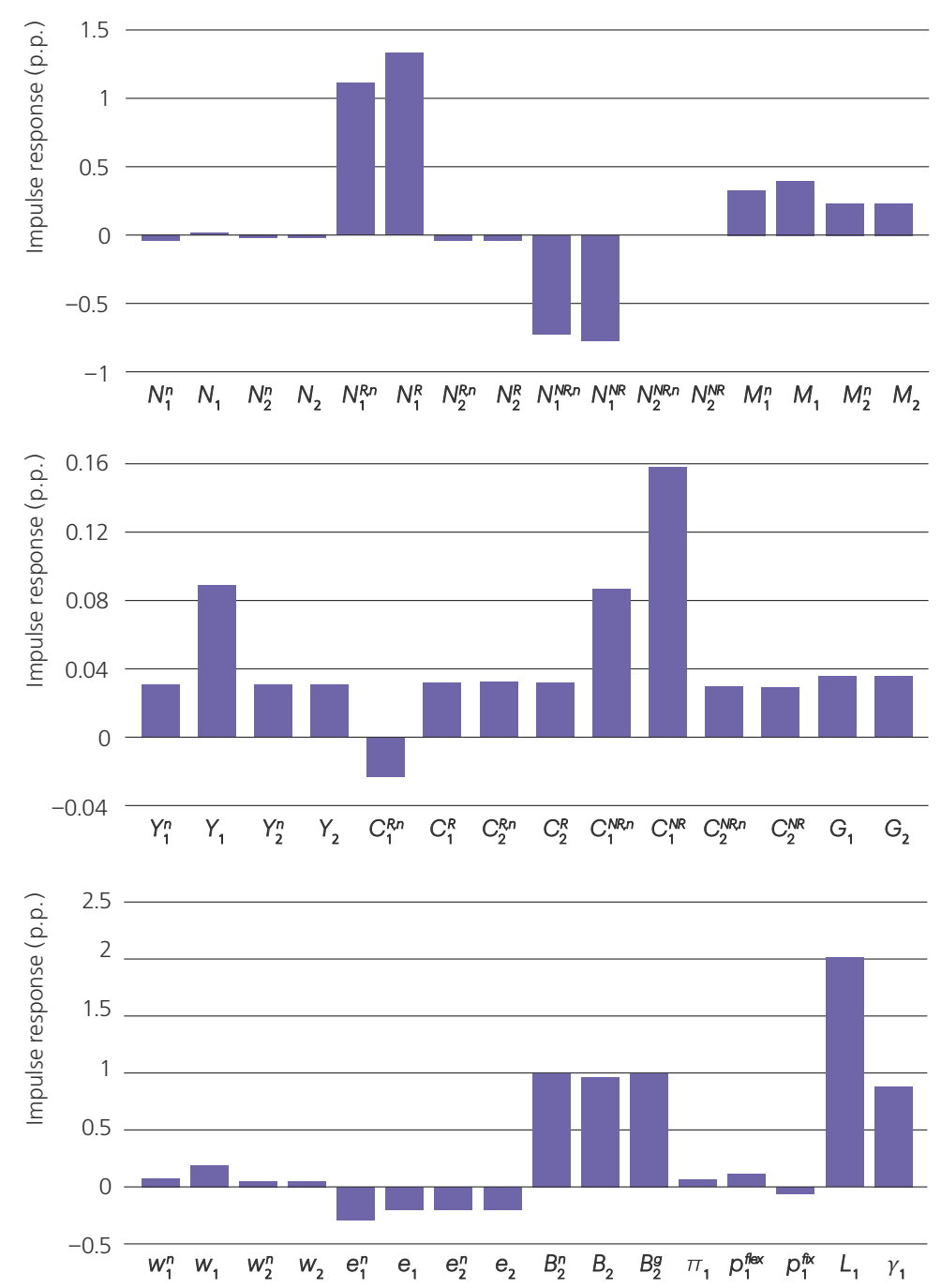

In the closed economy with flexible nominal prices, there is no way to reallocate a fraction of the date $t=1$ surplus to future periods. That means that the entire amount $\hat{M}_{1}=\hat{X}_{1}$ must be used in the production on date $t=1$. The relative abundance of imported inputs $\hat{M}_{1}$ compared with labour drives real wages $\hat{w}_{1}^{n}$ up and depresses the real price of the imported inputs $\hat{e}_{1}^{n}$, which is the real exchange rate. On date $t=2$, all real prices and allocations are back to their pre-shock levels. 
In the small open economy with Ricardian households only and flexible nominal wages, the endogenous response to $\hat{X}_{1}$ will be different. As shown in Figure 3, $\hat{e}_{1}^{n}$ and $\hat{e}_{2}^{n}$ drop by an equal amount, $\hat{w}_{1}^{n}$ and $\hat{w}_{2}^{n}$ rise by an equal amount, etc. In response to the shock to $\hat{X}_{1}$ on date $t=1$, the economy jumps immediately to a new steady state.

In the small open economy with flexible prices where both Ricardian and nonRicardian households are present, a shock to $\hat{X}_{1}$ will induce a greater growth in wages on date $t=1$ than on date $t=2$, which implies that non-Ricardian households will cut their labour supply on date $t=1$. Real appreciation on date $t=1$ will be more pronounced than on date $t=2$. The real interest parity implies that the real interest rate will rise on date $t=1$, which will stimulate Ricardian households to work more and consume less on date $t=1$.

Now, if we return to our small open economy with sticky date $t=1$ prices and both types of households present, it should be clear why the flexible-price equilibrium cannot materialise without monetary policy intervention. Recall that starting from date $t=2$ nominal prices are flexible, and the inflation target $\pi_{2}=0$ is achieved. If $i_{1}$ remains unchanged, so does the real rate. By the real interest parity, $\hat{e}_{1}$ and $\hat{e}_{2}$ change equiproportionally. The consequence is that Ricardian households consume too much and work too little on date $t=1$ compared with their flexible-price equilibrium quantities. The correcting response of monetary policy would be to raise $i_{1}$ if $\hat{X}_{1}>0$ and cut $i_{1}$ if $\hat{X}_{1}<0$. This is exactly that we observe in Figures 18 and 19.

Figures 21 and 22 show that this pattern survives if the structural balance fiscal rule is replaced with the balanced budget rule, with optimal monetary policy intervention becoming even more aggressive.

Our final exercise is to examine how the optimal policy mix with regard to the two shocks of interest changes if the degree of complementarity between labour and imported inputs rises. Figures 23 and 24 show optimal policy responses to the commodity-boom-unrelated credit growth shock and the oil price shock, respectively. In response to the credit boom shock, macroprudential policy tightens whereas monetary policy loosens, which contrasts to the case of $\gamma=1$ where monetary policy was neutral or slightly contractionary. The explanation is the following. Macroprudential tightening depresses aggregate demand and imports $\hat{M}_{1}$. The real prices of both inputs, $\hat{w}_{1}$ and $\hat{e}_{1}$, decline. Compared with the case of unit cross-elasticity of substitution between labour and imported inputs, $\gamma=1$, the drop in real wages will be greater in the case of lower substitutability, or higher complementarity, between labor and imported inputs, $\gamma=0.7$. This will eliminate any inflationary pressures created by higher credit spreads via marginal costs and final goods prices. It follows that there is no need for monetary contraction anymore, and the task of monetary policy now becomes closing the output gap. 
In the case of an oil price shock, the overall optimal response of monetary policy is the sum of the two: first, closing the output gap produced by tighter macroprudential policy and, as a result, a higher credit spread, and the second, correction of the intertemporal resource misallocation mentioned above. It turns out that, for this particular parametrisation, the second task of monetary policy dominates so that the optimal policy mix requires some monetary tightening as the value of the oil price shock grows.

Figure 21. Optimal responses of monetary and macroprudential policies to credit growth induced by an oil price shock on date $t=1$ : small open economy with a balanced budget rule and non-Ricardian households, $\eta=1$
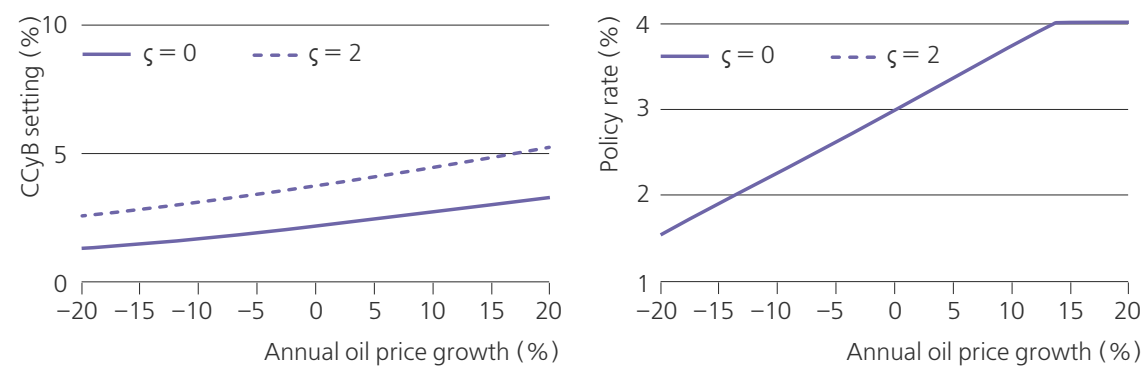

Figure 22. Optimal responses of monetary and macroprudential policies to credit growth induced by an oil price shock on date $t=1$ : small open economy with a balanced budget rule and non-Ricardian households, $\eta=0.5$
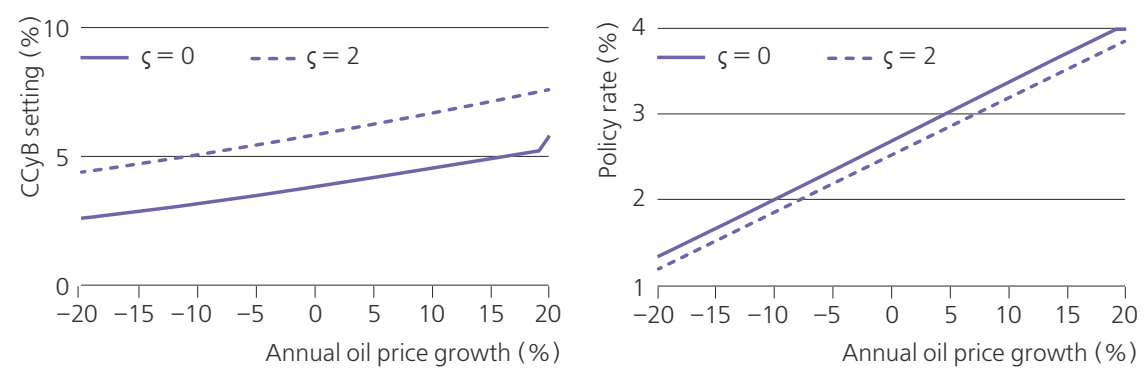

Figure 23. Optimal responses of monetary and macroprudential policies to a credit growth shock on date $t=1$ : small open economy with a structural balance fiscal rule and non-Ricardian households, $\eta=1, y=0.7$
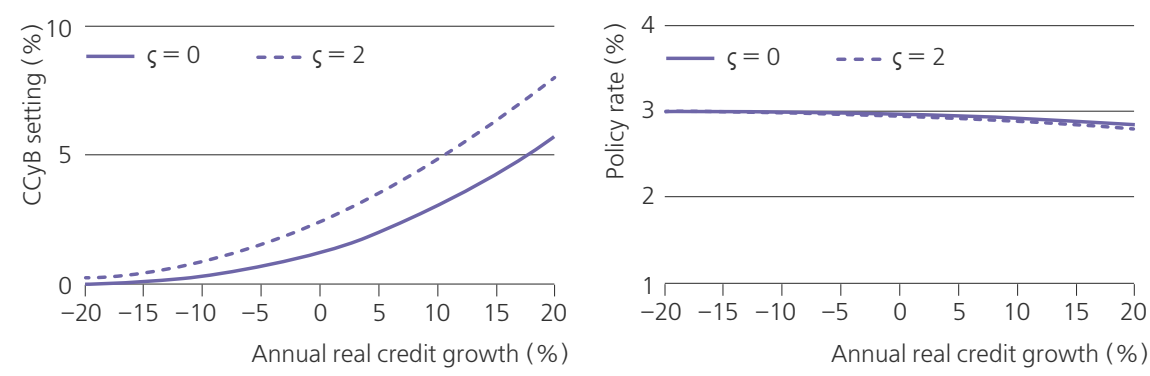
Figure 24. Optimal responses of monetary and macroprudential policies to credit growth induced by an oil price shock on date $t=1$ : small open economy with a structural balance fiscal rule and non-Ricardian households, $\eta=1, \gamma=0.7$
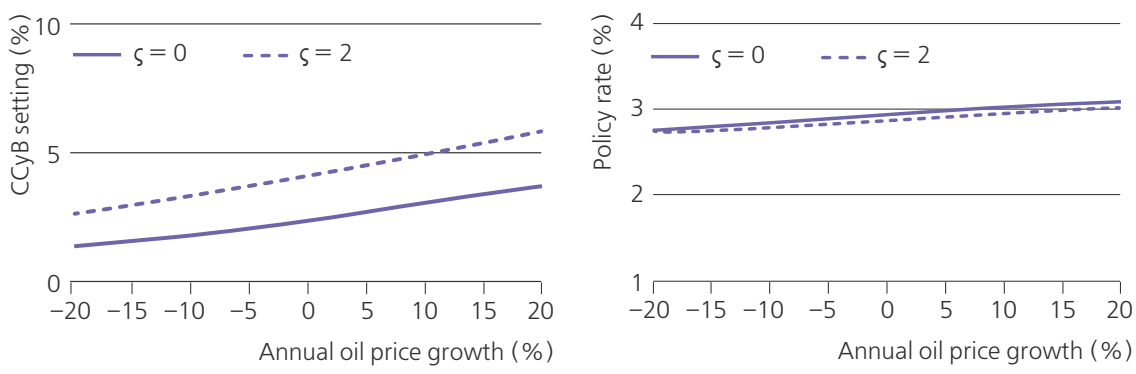

\section{Conclusion}

This paper studies the interaction between macroprudential and monetary policies in a simple New Keynesian model of a small open commodity-exporting economy under two different fiscal arrangements - balanced government budget and the structural balance fiscal rule - where financial frictions, credit, and financial instability are introduced ad hoc and calibrated based on empirical evidence. Are monetary and macroprudential policies complements or substitutes? The answer depends on the nature of the shock and particularities of the economic structure. We found that in the small open economy complementarity in the optimal policy mix is obtained when the degree of pass-through of credit spreads into marginal costs and prices is high enough. This contrasts with the closed economy case, where monetary and macroprudential policies are always substitutes (i.e. macroprudential tightening should be accompanied by monetary easing). If unwanted credit growth is brought on the back of a commodity boom, and some workers are hand-to-mouth with no ability to save or borrow, then monetary policy tends to be complementary to macroprudential policy since it bears the task of correcting intertemporal resource allocation distorted by sticky prices, thus, giving a hand to the structural balance fiscal rule. When there is more complementarity between domestic and imported production inputs, the two policies tend to be substitutes.

Being very stylised, our model lacks some important features. First, production firms do not borrow in our model, whereas they do in actual economies. To the extent that they can choose between borrowing in foreign vs. domestic currencies, this can limit the effectiveness of domestic monetary policy and raise the appeal of macroprudential policy. Second, macroprudential policy in our model is captured by a single parameter, which is labelled CCyB only for concreteness. In practice, a multitude of various macroprudential policy tools is available, and not all of them work through credit spreads. For example, stricter loan-to-value ratios (LTV) do not have a direct effect on spreads but presumably suppress unwanted credit growth. Analysing the optimal choice among different macroprudential tools certainly requires a richer model. Last but not least, in our model the short run is compressed 
to a single period, namely, date 1 when shocks materialise and nominal prices are sticky. To a great extent, our findings are driven by the monetary authority being reluctant to accept higher rate of inflation in the short-term perspective. In a fullyfledged dynamic model, this concern may not be so serious, since provided that inflation remains close to target in the medium term, the monetary authority can tolerate it temporarily overshooting target in the short term. It is not obvious at this point how robust out results are with respect to this modification of the model. We leave these and other extensions for future research.

\section{References}

Agénor, P.-R. (2016). Optimal Fiscal Management of Commodity Price Shocks. Journal of Development Economics, 122, pp. 183-196. doi: 10.1016/j.jdeveco.2016.05.005

Aikman, D., Giese, J., Kapadia, S. and McLeay, M. (2018). Targeting Financial Stability: Macroprudential or Monetary Policy? Bank of England Staff Working Paper, N 734.

Ajello, A., Laubach, T., López-Salido, D. and Nakata, T. (2019). Financial Stability and Optimal Interest Rate Policy. International Journal of Central Banking, 15, pp. 279-326.

Angelini, P., Neri, S. and Panetta, F. (2014). The Interaction between Capital Requirements and Monetary Policy. Journal of Money, Credit and Banking, 46(6), pp. 1073-1112. doi: 10.1111/jmcb.12134

Bejarano, J., Hamann, F., Mendoza, E. G. and Rodríguez, D. (2016). Commodity Price Beliefs, Financial Frictions and Business Cycles. Mimeo.

Ben Zeev, N., Pappa, E. and Vicondoa, A. (2017). Emerging Economies Business Cycles: The Role of Commodity Terms of Trade News. Journal of International Economics, 108, pp. 368-376. doi: 10.1016/j.jinteco.2017.07.008

Bergholt, D. (2014). Monetary Policy in Oil Exporting Economies. CAMP Working Paper Series Working Paper, N 5.

Catão, L. and Chang, R. (2013). Monetary Rules for Commodity Traders. IMF Economic Review, 61(1), pp. 52-91.

Charnavoki, V. (2019). International Risk-Sharing and Optimal Monetary Policy in a Small Commodity-Exporting Economy. Russian Journal of Money and Finance, 78(2), pp. 3-27.

Cúrdia, V. and Woodford, M. (2016). Credit Frictions and Optimal Monetary Policy. Journal of Monetary Economics, 84, pp. 30-65. doi: 10.1016/j.jmoneco.2016.10.003

Drechsel, T. and Tenreyro, S. (2018). Commodity Booms and Busts in Emerging Economies. Journal of International Economics, 112, pp. 200-218. doi: 10.1016/j.jinteco.2017.12.009

Drygalla, A. (2017). Monetary Policy in an Oil-Dependent Economy in the Presence of Multiple Shocks. IWH Discussion Paper, N 14.

Fernández, A., González, A. and Rodríguez, D. (2018). Sharing a Ride on the Commodities Roller Coaster: Common Factors in Business Cycles of Emerging Economies. Journal of International Economics, 111, pp. 99-121. doi: 10.1016/j.jinteco.2017.11.008 
Ferrero, A. and Seneca, M. (2019). Notes on the Underground: Monetary Policy in Resource-Rich Economies. Journal of Money, Credit and Banking, 51(4), pp. 953-976.

Gerali, A., Neri, S., Sessa, L. and Signoretti, F. M. (2010). Credit and Banking in a DSGE Model of the Euro Area. Journal of Money, Credit and Banking, 42(1), pp. 107-141.

Gertler, M. and Kiyotaki, N. (2015). Banking, Liquidity, and Bank Runs in an Infinite Horizon Economy. American Economic Review, 105(7), pp. 2011-2043. doi: 10.1257/aer.20130665

González, A., Hamann, F. and Rodríguez, D. (2015). Macroprudential Policies in a Commodity Exporting Economy. BIS Working Paper, N 506.

Gourinchas, P.-O. and Obstfeld, M. (2012). Stories of the Twentieth Century for the Twenty-First. American Economic Journal: Macroeconomics, 4(1), pp. 226-265.

Hamann, F., Bejarano, J., Rodriguez, D. and Restrepo-Echavarria, P. (2016). Monetary Policy in an Oil-Exporting Economy. Federal Reserve Bank of St. Louis Review, 98(3), pp. 239-261. doi: 10.20955/r.2016.239-261

Lorenzoni, G. (2014). International Financial Crises. In: G. Gopinath, E. Helpman, and K. Rogoff, eds. Handbook of International Economics. Elsevier: North Holland, pp. 689-740.

Lozej, M., Onorante, L. and Rannenberg, A. (2018). Countercyclical Capital Regulation in a Small Open Economy DSGE Model. ECB Working Paper, N 2144.

Medina, J. P. and Soto, C. (2016). Commodity Prices and Fiscal Policy in a Commodity Exporting Economy. Economic Modelling, 59, pp. 335-351. doi: 10.1016/j.econmod.2016.08.002

Menna, L. and Tobal, M. (2018). Financial and Price Stability in Emerging Markets: The Role of the Interest Rate. BIS Working Paper, N 717.

Schmitt-Grohé, S. and Uribe, M. (2018). How Important are Terms-of-Trade Shocks? International Economic Review, 59(1), pp. 85-111.

Schularick, M. and Taylor, A. M. (2012). Credit Booms Gone Bust: Monetary Policy, Leverage Cycles, and Financial Crises, 1870-2008. American Economic Review, 102(2), pp. 1029-1061. doi: 10.1257/aer.102.2.1029

Shousha, S. (2016). Macroeconomic Effects of Commodity Booms and Busts: The Role of Financial Frictions. Mimeo.

Snudden, S. (2016). Cyclical Fiscal Rules for Oil-Exporting Countries. Economic Modelling, 59, pp. 473-483. doi: 10.1016/j.econmod.2016.08.009

Van der Ploeg, F. (2019). Macro Policy Responses to Natural Resource Windfalls and the Crash in Commodity Prices. Journal of International Money and Finance, 96, pp. 263-282.

Woodford, M. (2003). Interest and Prices: Foundations of a Theory of Monetary Policy. Princeton and Oxford: Princeton University Press.

Woodford, M. (2012). Inflation Targeting and Financial Stability. Sveriges Riksbank Economic Review, 1, pp. 7-32. 


\section{Appendix}

\section{Log-linearised model for dates $t=1$ and $t \geq 2$}

Below we describe equations that characterise the solution of the model. Variable names dated $t=0$ refer to the original steady state values whereas variables dated $t=1$ and $t=2$ refer to the $\log$-deviations from date $t=0$ steady state on dates $t=1$ and $t=2$, respectively. For example, $Y_{0}$ is date $t=0$ output in levels, while $\hat{Y}_{1} \equiv\left(Y_{1}-Y_{0}\right) / Y_{0}$ and $\hat{Y}_{2} \equiv\left(Y_{2}-Y_{0}\right) / Y_{0}$ are date $t=1$ and date $t=2$ output, respectively, in logdeviations from $Y_{0}$. For periods $t=1$ and $t \geq 2$, the equilibrium is described by a system of log-linearised equations (37) - (60). The superscript $p s$ on the conditional expectation operator in equations (56) and (57) indicates that expectations of the private sector may deviate from fully rational on date 1 as private agents assign a zero probability to a financial crisis on date 2 :

$$
\begin{aligned}
& \alpha w_{0}^{1-\gamma} \widehat{w}_{2}+(1-\alpha) e_{0}^{1-\gamma} \hat{e}_{2}=0 \\
& \widehat{M}_{2}-\widehat{N}_{2}=\gamma\left(\widehat{w}_{2}-\hat{e}_{2}\right) \\
& M_{0} \widehat{M}_{2}=X_{0} \widehat{X}_{2}+(1-\beta) B_{0} \widehat{B}_{2}+(1-\beta) B_{0}^{g} \widehat{B}_{2}^{g} \\
& C_{0}^{N R} \hat{C}_{2}^{N R}=w_{0} \widehat{N}_{0}^{N R}\left(\widehat{w}_{2}+\widehat{N}_{2}^{N R}\right)+(1-\tau) e_{0} X_{0}\left(\hat{e}_{2}+\widehat{X}_{2}\right) \\
& \widehat{w}_{2}-\sigma \hat{C}_{2}^{N R}=\phi \widehat{N}_{2}^{N R} \\
& \widehat{w}_{2}-\sigma \hat{C}_{2}^{R}=\phi \widehat{N}_{2}^{R} \\
& G_{0} \hat{G}_{2}=\tau e_{0} X_{0}\left(\hat{e}_{2}+\hat{X}_{2}\right)+(1-\beta) e_{0} B_{0}^{g}\left(\hat{e}_{2}+\hat{B}_{2}^{g}\right) \\
& Y_{0} \hat{Y}_{2}=(1-v) C_{0}^{R} \hat{C}_{2}^{R}+v C_{0}^{N R} \hat{C}_{2}^{N R}+G_{0} \hat{G}_{2} \\
& Y_{0}^{\frac{\gamma-1}{\gamma}} \widehat{Y}_{2}=\alpha^{\frac{1}{\gamma}} N_{0}^{\frac{\gamma-1}{\gamma}} \widehat{N}_{2}+(1-\alpha)^{\frac{1}{\gamma}} M_{0}^{\frac{\gamma-1}{\gamma}} \widehat{M}_{2}
\end{aligned}
$$




$$
\begin{aligned}
& N_{0} \widehat{N}_{2}=(1-v) N_{0}^{R} \widehat{N}_{2}^{R}+v N_{0}^{N R} \widehat{N}_{2}^{N R} \\
& \widehat{M}_{1}-\widehat{N}_{1}=\gamma\left(\widehat{w}_{1}-\hat{e}_{1}\right) \\
& \left(\frac{\theta-1}{\theta}\right)^{1-\gamma} \hat{p}_{1}^{\text {flex }}=\alpha w_{0}^{1-\gamma} \widehat{w}_{1}+(1-\alpha) e_{0}^{1-\gamma} \hat{e}_{1}+\left(\frac{\theta-1}{\theta}\right)^{1-\gamma} \eta s_{1} \\
& C_{0}^{N R} \hat{C}_{1}^{N R}=w_{0} N_{0}^{N R}\left(\widehat{w}_{1}+\widehat{N}_{1}^{N R}\right)+(1-\tau) e_{0} X_{0}\left(\hat{e}_{1}+\hat{X}_{1}\right) \\
& \widehat{w}_{1}-\sigma \hat{C}_{1}^{N R}=\phi \widehat{N}_{1}^{N R} \\
& \widehat{W}_{1}-\sigma \hat{C}_{1}^{R}=\phi \widehat{N}_{1}^{R} \\
& G_{0} \hat{G}_{1}=\tau e_{0} X_{0}\left(\hat{e}_{1}+\hat{X}_{1}\right)-\beta e_{0} B_{0}^{g}\left(\hat{B}_{2}^{g}+\hat{e}_{1}\right)+e_{0} B_{0}^{g} \hat{e}_{1} \\
& Y_{0} \hat{Y}_{1}=(1-v) C_{0}^{R} \hat{C}_{1}^{R}+v C_{0}^{N R} \hat{C}_{1}^{N R}+G_{0} \hat{G}_{1} \\
& N_{0} \widehat{N}_{1}=(1-v) N_{0}^{R} \widehat{N}_{1}^{R}+v N_{0}^{N R} \widehat{N}_{1}^{N R} \\
& (1-\xi) \hat{p}_{1}^{\text {flex }}+\xi \hat{p}_{1}^{\text {fix }}=0 \\
& \hat{C}_{1}^{R}=\mathbb{E}_{t}^{p s}\left[\hat{C}_{2}^{R}\right]-\frac{1}{\sigma}\left(i_{1}+s_{1}\right) \\
& i_{1}=i^{*}+\mathbb{E}_{t}^{p s}\left[\hat{e}_{2}\right]-\hat{e}_{1} \\
& \widehat{G}_{1}=\widehat{G}_{2} \\
& e_{0} M_{0} \widehat{M}_{1}+\beta\left(e_{0} B_{0} \widehat{B}_{2}+e_{0} B_{0}^{g} \hat{B}_{2}^{g}\right)=e_{0} X_{0} \widehat{X}_{1} \\
& Y_{0}^{\frac{\gamma-1}{\gamma}} \widehat{Y}_{1}=\alpha^{\frac{1}{\gamma}} N_{0}^{\frac{\gamma-1}{\gamma}} \widehat{N}_{1}+(1-\alpha)^{\frac{1}{\gamma}} M_{0}^{\frac{\gamma-1}{\gamma}} \widehat{M}_{1}
\end{aligned}
$$

